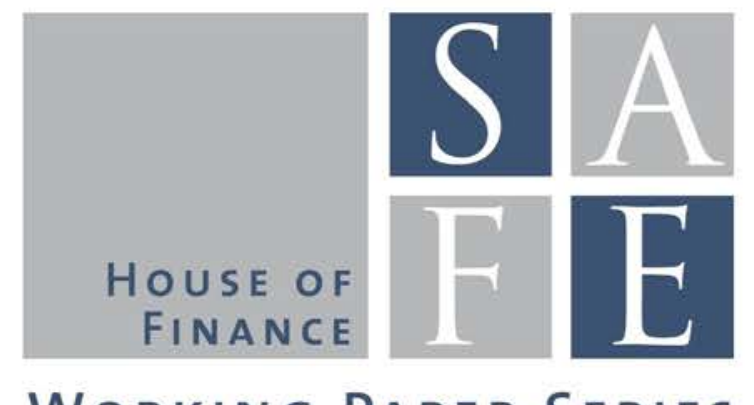

WORKING PAPER SERIES

Klaus Gugler - Michael Weichselbaumer - Christine Zulehner

\title{
Effects of Government Spending on Employment: Evidence from Winners and Runners-up in Procurement Auctions
}

SAFE Working Paper No. 213

SAFE I Sustainable Architecture for Finance in Europe A cooperation of the Center for Financial Studies and Goethe University Frankfurt 


\section{Non-technical summary}

In this paper, we estimate demand for labor when firms experience an increase in demand. We analyze public procurement auctions in the Austrian construction sector and compare the employment of the winner of an auction with the employment of the second ranked firm (i.e. the runner-up firm). Our empirical design rests on the assumption that the winning bidder and its runner-up have similar winning probabilities. When the winning probabilities are close enough to warrant similar expectations of winning, then the difference in employment between winner and runner-up measures the employment effect of the new contract. Thus, the realization of the positive demand shock due to winning an auction can be regarded as a surprise, and we are able to measure the exogenous element of the demand shock.

We use data on Austrian procurement auctions in the construction sector during the period beginning of 2006 to end of 2009 and information on firms' employment coming from the Austrian Social Security Database (ASSD). For all auctions, we know the identity of the winner and the runner-up, their bids and auction characteristics. The ASSD covers private sector workers on a daily basis, and includes a large sample of firms from administrative matched employer-employee data in Austria. The data allow us on the one hand to pin down demand shocks at a daily basis (winning an auction in contrast to the runner-up) and on the other hand to trace the daily evolution of the (net) number of employees of these firms as well as all hires and fires that take place thereafter.

Our main results show that the winning firm significantly increases labor demand in the weeks following an auction but only in the years before the recent economic crisis. It employs about 80 workers more after the auction than the runner-up firm. Most of the adjustment takes place within one month after the demand shock. Winners predominantly fire fewer workers after winning than runner-up firms. In the crisis, however, firms do not employ more workers than their competitors after winning an auction. This implies that second round effects of the fiscal stimulus measures were absent in Austria during that time period. 


\title{
Effects of government spending on employment: Evidence from winners and runners-up in procurement auctions*
}

\author{
Klaus Gugler ${ }^{\dagger} \quad$ Michael Weichselbaumer ${ }^{\ddagger} \quad$ Christine Zulehner ${ }^{\S}$
}

May 2018

\begin{abstract}
To estimate demand for labor, we use a combination of detailed employment data and the outcomes of procurement auctions, and compare the employment of the winner of an auction with the employment of the second ranked firm (i.e. the runner-up firm). Assuming similar ex-ante winning probabilities for both firms, we may view winning an auction as an exogenous shock to a firm's production and its demand for labor. We utilize daily data from almost 900 construction firms and about 3,000 auctions in Austria in the time period 2006 until 2009. Our main results show that the winning firm significantly increases labor demand in the weeks following an auction but only in the years before the recent economic crisis. It employs about 80 workers more after the auction than the runner-up firm. Most of the adjustment takes place within one month after the demand shock. Winners predominantly fire fewer workers after winning than runner-up firms. In the crisis, however, firms do not employ more workers than their competitors after winning an auction. We discuss explanations like labor hoarding and productivity improvements induced by the crisis as well discuss implications for fiscal and stimulus policy in the crisis.
\end{abstract}

JEL Classifications: D44, L10, L13

Keywords: labor demand, labor hoarding, construction procurement, first-price auctions, recent economic crisis, regression discontinuity design

\footnotetext{
${ }^{*}$ We thank Andrea Weber and seminar participants at the NFN Workshop at Vienna University of Economics and Business, University of Cologne and Goethe University Frankfurt for their comments and suggestions. This project received funding from the Austrian Science Fund (National Research Network S103). All errors and opinions are the authors' sole responsibility.

${ }^{\dagger}$ WU Vienna University of Economics and Business, Address: Welthandelsplatz 1, A-1020 Vienna, Austria, Email: klaus.gugler@wu.ac.at.

${ }^{\ddagger}$ WU Vienna University of Economics and Business, Address: Welthandelsplatz 1, A-1020 Vienna, Austria, Email: michael.weichselbaumer@wu.ac.at.

${ }^{\S}$ University of Vienna, Telecom ParisTech, WIFO Vienna, CEPR and Research Center SAFE, Address: OttoMorgenstern-Platz 1, A-1090 Vienna, Austria, Email: christine.zulehner@.univie.ac.at.
} 


\section{Introduction}

What happens to the level of employment when a firm experiences an increase in demand? Does the effect on employment differ in an economic crisis? What are the main channels of adjustment? What are the implications for fiscal and stimulus policy to counteract severe contractions? To answer these questions, we estimate the employment effects when a firm acquires a new contract in a procurement auction, allow for changes in firms' employment behavior in the recent economic crisis, and also assess the effect on hires and fires separately. For our empirical analysis, we address two concerns inherent in empirical research on labor demand (see for example, Addison et al. (2014)). The first concern is potential endogeneity. When a firm adjusts its workforce, it may be due to an exogenous demand shock or it may be due to some other factors such as positive or negative productivity shocks or simply due to unobserved firm heterogeneity. The second concern is related to the frequency of observations which are often only available on a yearly or quarterly basis. This might be too long for an analysis of the adjustment processes taking place within the firm after a shock. This paper tries to tackle both concerns.

We address the first concern with an innovative research set up. We analyze Austrian construction sector public procurement auctions and determine winning bids and runner-up bids. The empirical design rests on the assumption that the winning bidder and its runner-up have similar winning probabilities. When the winning probabilities are close enough to warrant similar expectations of winning (which we show is indeed the case), then the difference in employment between winner and runner-up measures the employment effect of the new contract. Thus, the realization of the positive demand shock due to winning an auction can be regarded as a surprise, and we are able to measure the exogenous element of the demand shock. Indication of comparability between the winner and the runner-up can be given by comparing their characteristics ex-ante. We find that they are similar in observables such as employment, wage level and distance between firm and project site - all of which are different for the other bidders with ranks three or higher in the auction. Thus, our empirical design provides quasi-experimental evidence on the link between demand for a firm's product and its labor input demand.

An unusual data set permits us to exploit daily information on auction outcomes and firm employment. This let us address the second concern by using daily data on the demand shock as well as the subsequent evolution of employment. For our empirical analysis, we use data on Austrian procurement auctions in the construction sector during the period beginning of 2006 
to end of 2009 and information on firms' employment coming from the Austrian Social Security Database (ASSD). For all auctions, we know the identity of the winner and the runner-up, their bids and auction characteristics. The ASSD covers private sector workers on a daily basis, and includes a large sample of firms from administrative matched employer-employee data in Austria (Zweimüller et al., 2009). The data allow us on the one hand to pin down demand shocks at a daily basis (winning an auction in contrast to the runner-up) and on the other hand to trace the daily evolution of the (net) number of employees of these firms as well as all hires and fires that take place thereafter. We also distinguish between blue and white collar workers, and investigate the channels how winning a contract influences firms' employment by assessing the effect on hires and fires, separately. Given this set-up, we argue that we are able to tackle the two main problems in labor demand research.

From the daily variations in our data we can observe that firms' reaction to a new contract is closely tied to the date when they win the contract. The winning firm significantly increases employment in the weeks following the auction. For the whole time period (2006-2009) it employs around 60 workers (2.1 percent of its workforce) more than the runner-up firm over the post-auction period of around four months. The adjustment is fairly quickly as within one month around three fourth of the adjustment process is finished. Most employment effects are due to blue collar workers (85 percent) as compared to white collar workers (15 percent). Our data stretch over the period 2006 to 2009 , and within that period lies the beginning of the recent economic crisis. In a specification that allows for the employment effect to vary during the crisis, we find the employment effect to increase to about 80 employees before the crisis. During the crisis, however, winner and runner-up display no employment reaction to the new contract. Differences between hiring and firing patterns show that winners achieve the adjustment by firing fewer workers after the auction than runners-up. During the crisis, the differences in hires and fires between winner and runner-up disappear as well.

Our results imply a strong reaction of employment to demand changes before the crisis, however a labor demand reaction with respect to output of essentially zero during the economic downturn. One interpretation would be labor hoarding, since in the crisis winning firms hold their workforces stable. Sector-wide statistics are also consistent with labor hoarding in the crisis. Output in the Austrian construction sector decreased by around 2\% from 2008 to 2009, but worked hours essentially stayed flat in that time period. ${ }^{1}$ However, the results in the period before the crisis

\footnotetext{
${ }^{1}$ See http://www.statistik.at/web_de/statistiken/wirtschaft/produktion_und_bauwesen/konjunkturdaten/index.html. See Huber et al. (2017) for corroborating macroeconomic evidence of relatively stable employment compared to output in the recent economic crisis in Austria.
} 
cannot easily be explained by labor hoarding alone. The runner-up lets go the differential number of workers that are not needed anymore after a contract is awarded to the winner, and the winning firm displays a large labor demand reaction. An alternative/additional explanation would be a change in productivity due to the increased competition in the crisis. ${ }^{2}$ Thus, labor markets appear to be working differently in downturns as compared to "normal" times.

Based on our empirical approach we argue that we estimate causal effects of the treatment, i.e., winning the auction, because the only significant observable difference between the winning firm and runner-up firm is the fact that the former won the auction and the latter lost the auction by a small margin. Robustness checks further support our findings. First, we rule out seasonal effects by including dummies for each sample month. Labor demand in the construction sector is determined by weather conditions that vary over the year and the additional controls account for these. Second, we check the results relative to higher-ranked bidders who serve as an additional control group and let us substantiate our effects. Third, we explore the similarity of the winner and the runner-up in more detail. Although first and second in the auction, the winner' and the runner-up's winning probabilities might be quite different. Using a linear probability model, we are able to assess the similarity in winning probabilities and run a further robustness check with a restricted sample. Fourth, we constrain the relative difference in bids between winner and runner-up. This relative difference is the money left on the table in the auction, and if bidders bid optimally in the auction, it may serve as a proxy for differences in bidders' cost valuations for the project. This lets us rule out differences potentially indicated by large margins or differences in bidders' valuations. Finally, we check for any contamination due to additional auctions in the evaluation period.

Relating to the questions stated in the beginning, we find that firms employ more people when enjoying an increase in demand, however they do so only in "normal" times. In a severe crisis they do not respond by employing more workers if demand goes up incrementally. If they increase employment, they do so fairly quickly. We observe that within one month around three fourth of the adjustment process is finished. The main channel of adjustment is not hiring more workers but firing fewer workers after winning an auction than runners-up. What are the implications of our results for fiscal and stimulus policy to counteract severe contractions? Since our auctions consist of public procurement auctions we can also shed some light on this question. We find that the employment effect of an exogenous increase in demand was essentially zero in the crisis period of

\footnotetext{
${ }^{2}$ In Gugler et al. (2015a), using a similar, but less detailed dataset, we investigate the effects of the recent economic crisis on firms' bidding behavior and markups in first price sealed bid auctions. Applying a private value auction model, we find pro-cyclical markups.
} 
our sample (we determine October 2008 as the beginning of the crisis in Austria). That is the winner of the auction did not hire more nor fire fewer workers than the runner up. This implies that second round effects of the fiscal stimulus measures were absent in Austria during that time period.

The remainder of the paper is organized as follows. In the next section, we relate our approach to the literature. Section 3 describes our research design and sets up the empirical model. We describe our data, give institutional details, and provide evidence on the similarity of the winners and losers justifying our research design. Section 4 describes the empirical results graphically and with regression analysis. Further robustness checks are given in Section 5. Section 6 provides a discussion on the possible reasons for the observed pattern of employment responses and Section 7 concludes.

\section{Related literature}

Our setting studies the effect of additional output contracted by a firm on labor demand and the adjustment process that consequently takes place. Adjustment of labor has been studied extensively, and faces two important challenges. First, potential endogeneity problems must be tackled (e.g. firm heterogeneity or productivity differences; see Bond and Van Reenen (2007) for major studies of estimating labor adjustment). Second, observations are often available only on a yearly or quarterly frequency, which can be too low for some forms of interesting adjustment processes (for a recent overview, see Addison et al. (2014); Kramarz (2014)). Our research design addresses both concerns raised in empirical research on labor demand. The first concern might be considered as minor in our analysis, since the winner and the runner-up are similar in their main characteristics and, in particular, their winning probabilities are similar. Thus, the realization of the positive demand shock due to winning an auction can be regarded as a surprise, and we are able to measure the exogenous element of the demand shock. We address the second concern by using daily data on the demand shock as well as the subsequent evolution of employment.

From a production function logic, one expects a non-negative effect of an increase in the firm's output on its level of employment (see Nickell (1984) or Bresson et al. (1996)). The question is how large the response in labor demand is, and how it is distributed over time, i.e. whether expectations of a product demand increase (winning the auction) leads to a build-up of labor already before the date of the demand realisation and how the labor adjustment process evolves after this demand 
uncertainty is resolved. An early examination of labor as an input factor that faces fixed costs of adjustment is by Oi (1962). Given the presence of hiring and training costs, the author argues that "Even under perfect competition wages would be equated to marginal products if and only if labor is a completely variable factor". Hamermesh (1989) gives plant-level evidence, using monthly data, on the relevance of fixed costs, leading to labor adjustment that displays jumps which are not coincidental with changes in production. The resulting "labor hoarding" was also used to explain the existence of counter-cyclical productivity (see Biddle (2014)), although this counter-cyclicality seems to have disappeared in the recent crisis (see Galì and van Rens (2015)).

A rather small literature addresses the estimation of labor demand from an industrial organization perspective. It tackles particular aspects of labor demand in combination with questions on turnover of businesses (see e.g. the survey by Caves (1998)), innovation and productivity (see e.g. Bresnahan et al. (2002) and Lachenmaier and Rottmann (2011)), and the effects of mergers on labor demand (see e.g. Gugler and Yurtoglu (2004)).

Our research design has some similarities to other studies. Although questions unrelated to this study are at the center of the following papers, all of them exploit a sample of winners and losers in contests to construct a counterfactual outcome of the winner had he not won the contest. While we assess labor demand and use an auction as the contest, Greenstone et al. (2010) quantify agglomeration spillovers and compare changes in total factor productivity (TFP) among incumbent plants in "winning" counties that attracted a large manufacturing plant and "losing" counties that were the new plant's runner-up choice. Prior to the new plant opening, the winning and losing counties had similar trends in TFP. The empirical results show that incumbent plants' TFP is 12 percent higher in winning counties five years after the opening. They also find that this productivity spillover is larger for plants sharing similar labor and technology pools with the new plant. Malmendier et al. (2012) analyze whether acquiring firms profit from their acquisitions or whether acquiring CEOs overbid and destroy shareholder value. To answer these questions, they estimate the long-run abnormal returns to mergers exploiting detailed data on merger contests. Their results show that bidder returns are closely aligned in the years before the contest, but winners underperform losers by 50 percent over the following three years. Lee and Mas (2012) estimate an average effect of unionization in public firms on cumulative abnormal returns. They find close wins in votes for new unionization are associated with a reduction in the firm's market value. Recently, Ferraz et al. (2015) use a similar strategy to ours in Brazilian government procurement contracts when analyzing the effects of winning on subsequent firm growth. 
Finally, this paper relates to the literature on stimulus and (local) multiplier effects. Ramey (2011a) and Parker (2011) discuss the difficulties in the literature to evaluate stimulus packages. Nekarda and Ramey (2011) test the predictions of neo-classical and neo-Keynesian models aggregated on the level of industries. Ramey (2011a) additionally surveys the literature on stimulus spending and concludes that the multiplier can take on a large range of values. While many studies find positive employment effects, some studies even find negative effects. Somewhat in contrast to us, several studies find larger multipliers during times of higher slack. Interestingly, by many studies the implied costs per job created is estimated to be around 35,000 USD. Our estimates imply smaller costs per job created before the crisis (around 15,000 euro) but higher costs in the crisis (see below). Papers that report negative effects for fiscal intervention are Knight (2002) and Faggio and Overman (2014). Knight (2002) finds that once one controls for the endogeneity between grant receipts and preferences for public goods, federal highway grants crowd out state highway spending, leading to little or no increase in net spending in the US. These results are consistent with our results that stimulus measures in the recent crisis in the Austrian construction sector had no significant effects on employment. Faggio and Overman (2014) using English data at the Local Authority level for 2003 until 2007 find no identifiable effect of public sector employment on on total private sector employment.

Mixed results are reported by Feyrer and Sacerdote (2011). The authors analyze the American Recovery and Reinvestment Act (ARRA) and report significant heterogeneity by type of spending. While transfers to local governments and school districts to support teachers and police had no positive effect on employment, programs funding support for low income households generated the largest employment response. According to the results, building projects generate a smaller, but still substantial response. Cross state regressions reveal costs per job of around 170,000 USD, which is at the upper bounds of estimates in studies cited by Ramey (2011a). Positive effects of fiscal intervention are reported in the following studies. Using Swedish data, Moretti and Thulin (2013), show that when a local economy generates a new job by attracting a new business in the traded sector, a significant number of additional jobs are created in the non-traded sector. They also show that this multiplier effect is particularly large for jobs with high levels of human capital and for high-technology industries. See also Moretti (2010) for estimates on the US. While the authors concentrate on the effect of local development policies and which jobs are particularly valuable, we focus on the direct effect of government spending on job creation and whether this direct effect differs according to the general state of the economy. Chodorow-Reich et al. (2012) find that ARRA 
transfers to states had an economically and statistically robust positive effect on employment.

\section{Empirical approach}

This section introduces our empirical approach. We start by describing the econometric model, stating the basic specification and outline an extension that compares the effect of winning a contract before and in the recent economic crisis. After a description of the data we use for our empirical analysis, we give some background information on the Austrian labor market and the organization of procurement auctions. Summary statistics are given and extended to a comparison of winners and runners-up. Finally, we discuss the start of the crisis.

\subsection{Econometric model}

Estimation of the effect of winning an auction on any outcome relies on a valid counterfactual. We argue that a comparison between winner and runner-up provides such a valid counterfactual. Similarity before the event between the two groups of companies in the relevant covariates as well as the outcome measure itself support the view that the difference after winning can identify the auction effect on, e.g., employment. In the first part of our empirical results we address the comparability of the pre-event variables between the two groups, both for the outcome variables and for relevant characteristics.

After establishing the similarity of winners and runners-up, we estimate the average effect of winning an auction on the winner. The basic regression consists of the cross section of all winners and runners-up - that is, the bidders ranked first and second from each auction. Auctions are indexed with subscript $j$. The outcome is observed on the level of firm $i$. An observation is either before the auction announcement data, $t<0$, or after the announcement, $t>0$. The basis for estimating the effect of an additional construction project on the number of employees is:

$$
y_{i j t}=\alpha+\beta \times 1(\text { post })_{t}+\gamma \times 1(\text { Winner })_{i j}+\theta \times 1(\text { post })_{t} \times 1(\text { Winner })_{i j}+\varepsilon_{i j t},
$$

where $\theta$ measures the average employment effect on the winner. Each auction has an exact date when the contract is awarded to one firm. Employment records in our data source are on a daily basis, which allows us to measure the dummy variable post precisely starting after the day the contract was awarded. We run our regressions in levels and in first differences. For the latter, 
we follow Card and Krueger (2000). To assess the effects of the recent crisis on employment, we additionally estimate a second equation with an interaction of the dummy variable for the winner after the event and a dummy variable for the crisis:

$$
\begin{aligned}
y_{i j t}=\alpha & +\beta \times 1(\text { post })_{t}+\gamma \times 1(\text { Winner })_{i j}+\theta \times 1(\text { post })_{t} \times 1(\text { Winner })_{i j} \\
& +\kappa \times 1(\text { Crisis })_{j}+\mu \times 1(\text { Crisis })_{j} \times 1(\text { Winner })_{i j}+\nu \times 1(\text { Crisis })_{j} \times 1(\text { post })_{t} \\
& +\lambda \times 1(\text { post })_{t} \times 1(\text { Winner })_{i j} \times 1(\text { Crisis })_{j}+\varepsilon_{i j t} .
\end{aligned}
$$

While $\theta$ now measures the average employment effect on the winner before the crisis, $\lambda$ measures the differential effect of winning during the crisis compared to winning before the crisis. Our specifications assume that pre-existing trends in employment are similar for winners and runnersup. We test this assumption in the empirical analysis in Section $4.1 .^{3}$

\subsection{Data and background}

For our empirical analysis we draw on two data sources. ${ }^{4}$ The first provides data on Austrian procurement auctions in the construction sector during the period 2006-2009. The data come from an Austrian construction company. For all auctions in both building and heavy construction where this company took part either as the parent company itself or through a subsidiary, we obtained own and competitors' bids, and bidders' and auction characteristics. All auctions are awarded to the bidder with the lowest price (bid), i.e. we analyze first price sealed bid auctions. The total value, measured by the winning bids, of more than 3,000 auctions is 6 billion euro (CPI-deflated, 2006). Each auction record gives information on the number and identity of all bidders, a short description of the project, the bids and the day the project was awarded to the winning bidder. According to the data providing company, the database covers more than $80 \%$ of all auctions which must be conducted according to the Austrian Public Procurement Law. ${ }^{5}$ The data reflect on average $14 \%$ of Austria's total construction sector over our sample period.

Second, for a large subsample of bidders we have information on their employee structure and wages, based on the records of the Austrian Social Security Database (ASSD). This database

\footnotetext{
${ }^{3}$ See Wolfers (2006) for a discussion on time trends in a difference-in-difference context.

${ }^{4}$ Additional information on the industry and data is available in Gugler et al. (2015a) and Gugler et al. (2015b).

${ }^{5}$ All Austrian public institutions are subject to the Federal Public Procurement Law ("Bundesvergabegesetz"). This law specifies the legislative framework for public procurement, which includes services like cleaning, facilities like computing or furniture, and construction such as rails, roads, schools and other public buildings, etc. Our data are exclusively on procurement from the construction sector.
} 
covers the universe of private sector workers in Austria since the year 1972 (Zweimüller et al., 2009). All employees in Austria are covered by mandatory social security and therefore included in the database. As payment for social insurance benefits draws on insurance status on a daily basis, data on employment is available on that level. We determine a window of 90 days (working days, Monday to Friday) before and 90 days after the auction and for each day in this window, calculate the number of employees in the firm and their individual wage from the ASSD. Blue and white collar workers are distinguished.

Finally, we calculated backlog used by a firm at a point in time as in Jofre-Bonet and Pesendorfer (2003). Each time a firm wins, backlog of this firm increases by the value of the project. Projects are assumed to be worked off linearly over their construction period, thereby releasing capacity. Each firm's backlog obtained is standardized by subtracting its mean and dividing by its standard deviation. ${ }^{6}$ Transportation costs are measured by the driving distance of a firm to a construction site. $^{7}$

The final sample includes 3,081 auctions and contains data from 2,820 winners and 2,804 losers. Table 1 summarizes the bidder characteristics. As expected, the average bid of the winners is lower than that of the losers. While winners receive on average 2.014 million euro for a construction contract, a firm coming in second expected 2.141 million euro in payments for the contract. The number of bids per case (auction) is equal to 7.35. The average firm in our sample employs 2,353 workers, of which 1,591 are blue collar workers and 675 are white collar workers.

\subsection{Comparison of winners and runners-up}

We rely on the runner-up in first-price auctions to identify a control group. The runner-up has the second-lowest bid, often relatively close to the winner of the auction. Similarity of the groups of winners and runners-up with respect to the outcome variable (employees), among others, before the event of winning is crucial to the research design. We compare the pre-event variables between winners and runners-up, and the winners to the other bidders in each of the auctions. Table 2 demonstrates the similarity of winners and runners-up before the event. ${ }^{8}$

\footnotetext{
${ }^{6}$ We use planned construction duration, instead of actual, and estimate construction duration, when it is not available, using a log-log regression of contract duration on size.

${ }^{7}$ For firms with multiple plants, we use the distance between the headquarter and the construction site as plant locations are not available. However, different locations of a firm are often operated as subsidiaries and distances are then calculated accordingly.

${ }^{8}$ Note that the group of runners-up can be contaminated after the event. Firms may win one auction and be the runner-up in another auction on the same day. We drop such runners-up in estimating the effects of the event of winning a contract. Also note that winners and runners-up in the sample can come from different auctions. The Appendix A contains results for the subset of auctions where both winner and runner-up are present in our data.
} 
Table 1: Summary statistics

\begin{tabular}{lrrrrrr}
\hline \hline & \multicolumn{1}{c}{$\begin{array}{c}\text { Mean } \\
(1)\end{array}$} & $\begin{array}{r}\text { Std. Dev. } \\
(2)\end{array}$ & $\begin{array}{c}\text { 10th } \\
(3)\end{array}$ & $\begin{array}{c}50 \text { th } \\
(4)\end{array}$ & $\begin{array}{r}\text { 90th } \\
(5)\end{array}$ & $\begin{array}{c}\text { Obs. } \\
(6)\end{array}$ \\
\hline & & & & & & \\
Bid of winner & $2,014,431$ & $6,440,218$ & 180,166 & 782,294 & $3,657,371$ & 2,820 \\
Bid of runner-up & $2,141,625$ & $6,705,313$ & 198,451 & 831,398 & $3,952,979$ & 2,235 \\
No. of bids & 7.35 & 3.00 & 4 & 7 & 11 & 2,820 \\
Employees & $2,353.29$ & $2,983.14$ & 50 & 537 & 7,956 & 10,110 \\
Employees, blue & $1,590.97$ & $1,998.07$ & 29 & 414 & 5,192 & 10,110 \\
Employees, white & 675.47 & 896.86 & 8 & 155 & 2,473 & 10,110 \\
Wage & 93.85 & 10.31 & 78.39 & 96.37 & 104.71 & 10,110 \\
Wage, blue & 85.96 & 8.49 & 75.38 & 88.02 & 93.71 & 10,110 \\
Wage, white & 115.97 & 12.45 & 101.28 & 120.20 & 125.67 & 10,110 \\
Backlog & -0.03 & 0.72 & -0.92 & -0.06 & 0.85 & 10,110 \\
Distance & 141.34 & 127.98 & 10.96 & 103.81 & 329.10 & 5,045 \\
\hline
\end{tabular}

Note: Summary statistics of the winners and runners-up appearing as cases in our sample. Bid appears only once for each case and rank, the number of bids only once per case. The other variables' statistics contain data before and after winning the contract. Backlog is standardized by subtraction of the mean and division by the standard deviation on the firm level. Wages are yearly wages divided by the number of days of the year and thus measured per day. All monetary values are in 2006 euro.

Table 2: Winners, runners-up and rank 3-5

\begin{tabular}{|c|c|c|c|c|c|}
\hline & $\begin{array}{c}\text { Winners } \\
(1) \\
\end{array}$ & $\begin{array}{c}\text { Runners-up } \\
(2) \\
\end{array}$ & $\begin{array}{l}\text { Diff. } \\
(3)\end{array}$ & $\begin{array}{c}\text { Others } \\
(4)\end{array}$ & $\begin{array}{c}\text { Diff. } \\
(5)\end{array}$ \\
\hline Employees & $2,658.38$ & $2,610.36$ & -48.02 & $1,894.46$ & $-763.91^{* *}$ \\
\hline Employees, blue & $1,783.19$ & $1,750.35$ & -32.84 & $1,274.24$ & $-508.96^{* *}$ \\
\hline Employees, white & 776.54 & 764.02 & -12.52 & 548.61 & $-227.93^{* *}$ \\
\hline Wage & 94.32 & 94.53 & 0.21 & 92.98 & $-1.34^{* *}$ \\
\hline Wage, blue & 86.41 & 86.22 & -0.18 & 85.37 & $-1.03^{* *}$ \\
\hline Wage, white & 116.44 & 116.51 & 0.07 & 114.83 & $-1.61^{* *}$ \\
\hline Backlog & -0.07 & -0.00 & $0.07^{* *}$ & 0.01 & $0.08^{* *}$ \\
\hline Distance & 150.51 & 148.27 & -2.25 & 142.29 & $-8.22^{* *}$ \\
\hline Observations & 2,820 & 2,804 & & 2,820 & 14,440 \\
\hline
\end{tabular}

Note: The numbers of observations for winners and runners-up differ because of missing values. Significance levels: ** $\mathrm{p}<0.01,{ }^{*} \mathrm{p}<0.05$.

A comparison of column (1) with (2) and (4) shows that the rank closest to the winner produces a good comparison group, but not the other firms that participate in the auctions. In particular, the number of employees and wages of winners and runners-up are similar, but larger than that for other firms. The next section also shows that pre-auction employment trends are similar between winners and runners-up. While the backlog of winners is statistically significantly smaller than that for runners-up, there is no big difference economically (0.07 standard deviations).

The corresponding statistics to Table 2 for this selected "pairs-only"-sample are in Table A.2; summary statistics as in Table 1 are in Table A.1. 


\subsection{Economic crisis}

Our empirical model will also take into account the recent economic crisis by estimating differential treatment effects for the crisis period. The crisis dummy is intended to capture the effect of a change in firms' employment pattern caused by the economic crisis. It is therefore essential to determine when the crisis started. To make this judgement, we look at the stock and inflow of construction works and at indicators that address expectations in the sector. Relating the crisis start to macro data on stock and new orders follows our approach in Gugler et al. (2015a). Data on new orders already incorporate information about the future of the sector. To put further weight on the relevance of expectations on the economic development similar to the approach in Ramey (2011b), we extend the evidence to indicators on expectations and some narrative evidence on the expectations of increased government spending.

Economy-wide records on the stock of contracts outstanding and the new orders in the construction sector are shown in Figure 1. The left graph of Figure 1 provides the raw series and exhibits strong seasonal fluctuations, which make it hard to discern changing trends. For that reason, the right graph of Figure 1 is based on a 12-month trailing moving average for each series. After a longer period of increasing contract amounts for both series, the inflow of contracts shows a decrease around March 2009, going below the value of the dip in August 2008. The stock of contracts appears to be negatively affected as of September 2009, when it falls below the dip in the beginning of 2008. Both series are trailing moving averages and include the effects of the month in question and the 11 months before. Therefore, for each month in the moving average, we subtract 11 months for the earliest month that affects changes in the series. The reduction of aggregate contract amounts therefore seems to have started in April 2008 for new contracts, and October 2008 for the stock of contracts.

Besides the likely importance of the stock and new orders of contracts as measures for the realized path of future activity, they may not contain all information about the expectations that firms' managers have. We use two available sources to obtain measures for expectations of construction firms, potentially affecting employment behavior. First, the Economic Sentiment Indicator (ESI), published by the European Union, from which we use the country-specific sub-series for the construction sector. Two questions are considered in the data for the ESI: Is the stock of orders sufficient? How will total employment develop over the next 3 months? For each question, the difference of positive and negative answers relative to all answers is calculated. The series is the 
Figure 1: Stock of contracts and new orders
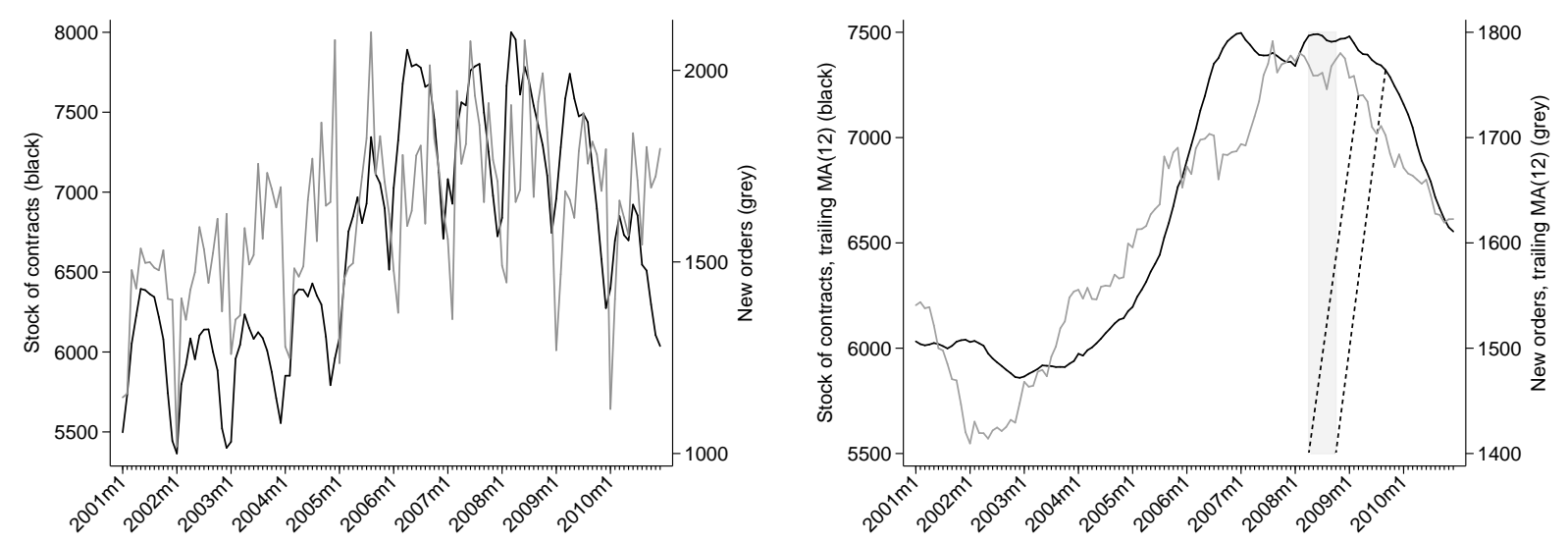

Notes: The shaded area encompasses the period of the potential crisis start, derived from the stock of orders and new orders. Values are in million 2005 euro. Data from Statistik Austria.

average of these two numbers. Second, the Business Cycle Survey from the Austrian Economic Chamber, which publishes the "new orders indicator" (NOI), where firms answer the question: Do you expect new orders for the current and subsequent quarter to be higher compared to the same quarter in the previous year? The NOI is the difference in percentage points between positive and negative answers.

Both indicators reveal a very close relationship in Figure 2. Both indicators suggest that expectations of the respondents have substantially deteriorated by October 2008. Somewhat in line with official statistics, the ESI - containing judgement on the stock of contracts, too resembles the inertia of the stock of contracts series in Figure 1, while the NOI - where the question relates to new orders - falls earlier. The sentiment indicators do not support the early date of April 2008 which we drew from inflow of new contracts, despite appearing to be much more directed toward expectations. We see the two indicators as support for choosing October 2008 as a reasonable, rough approximation of expected changes in employment policies by firms, and use the date to define our dummy for the start of the crisis.

Can we observe changes in employment patterns by looking at employment directly? As the economy-wide contract variables in Figure 1, the number of employees in construction firms display strong seasonal variation, shown on the left side of Figure 3. The right side of the figure uses the trailing moving averages again, and compares the evolution of employment to the stock of contracts. Employment data count all employees of the winning and runner-up firms in our sample. Both moving averages turn around in January 2009; but while the stock of contracts maintains the 
Figure 2: Measuring expectations in the construction sector

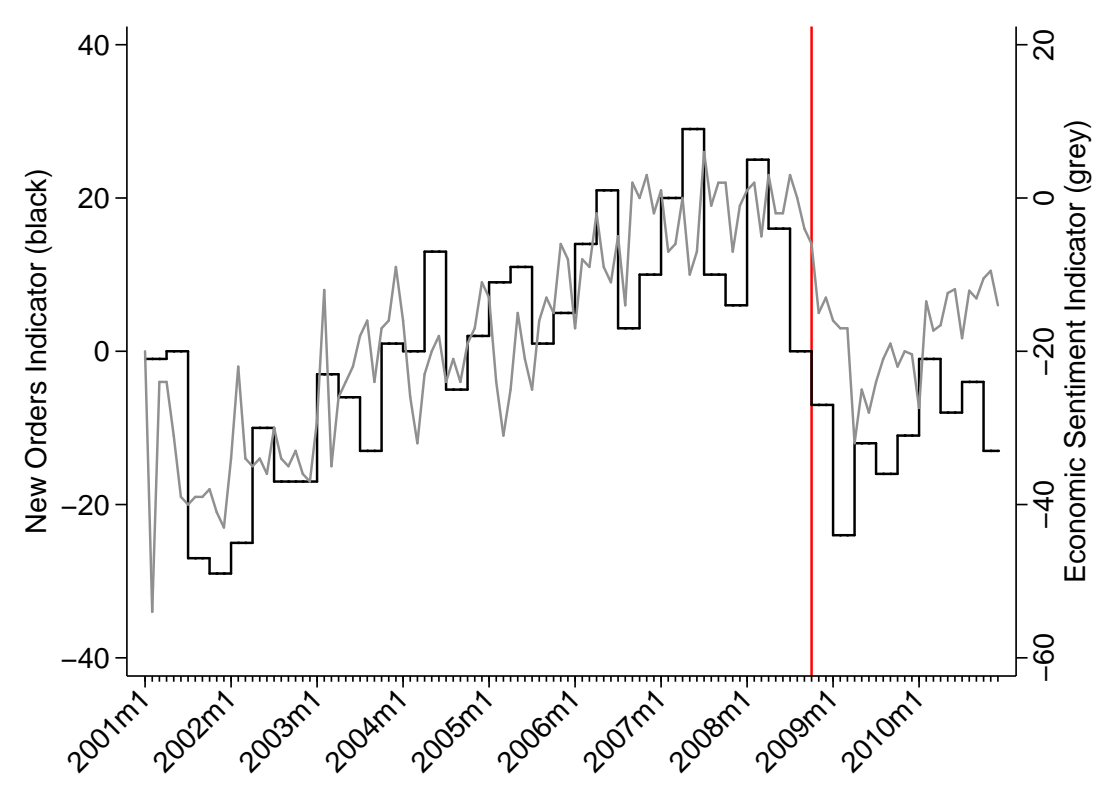

Notes: The Economic Sentiment Indicator is published by the European Union. The graph shows the series for the construction sector. Seasonally adjusted by Eurostat. Sample size for Austria is about 10 percent of the 4,134 (value for 2010) construction firms with 15 employees or more, with a response rate of about 50 percent. Construction firms covered correspond to about 15 percent of employment in the sector. (Source: European Commission, Business and Consumer Surveys.)

Business Cycle Survey: The Austrian Economic Chamber publishes the new orders indicator. The index covers some 430 firms, employing about 13,400 workers, on average. (Source: Austrian Economic Chamber, Quarterly Reports on the Business Cycle Inquiry of KMU-Forschung Austria.)

downward trend, the employment drop comes to a halt in April 2009 and simply remains flat in the 12-month average, again indicating that some change of employment behavior could have taken place in the crisis.

Government intervention A stimulus package, containing funds for infrastructure investment of 900 million euro (railroads: 700, roads: 200), was passed by the parliament on 28 October 2008, a second package contained 875 million euro for infrastructure investment (public buildings) passed on 23 December 2008. The total of 1.775 billion euro (about 11 percent of total value added in the construction sector in 2008) was targeted at the construction sector and scheduled for the years 2009 to 2012. Tracing back in time the information about plans to pass stimulus packages, one does not find early positive indications. Mid of September 2008, the chairman of EU finance ministers stated that stimulus packages are not reasonable, after a meeting of EU finance ministers - a position that the Austrian minister of economic affairs also stated publicly at the end of July 2008. On 28 September 2009, national elections took place. On the day before the election, the minister 
Figure 3: Employees of the sample firms
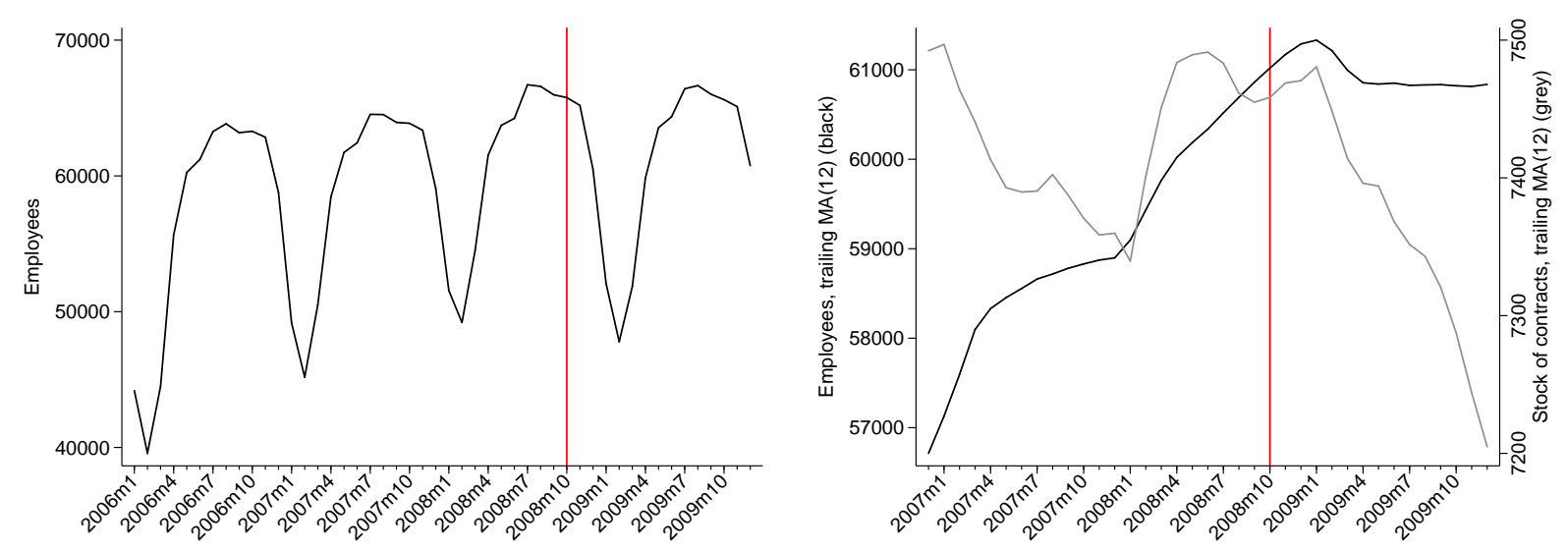

Notes: The left graph in this figure shows the number of employees in construction firms; the right graph shows uses the trailing moving averages, and compares the evolution of employment to the stock of contracts.

of economic affairs opined that a stimulus package may not be necessary; the finance minister did not address the issue; the front-runner of the largest party — then minister of transport — was in favour of stimulus package, without mention of size and targets. That the government would vote for stimulus was - in our reading of past media reports - not predictable until a few weeks before the binding decision. ${ }^{9}$

\section{Results}

The presentation below of the empirical results of the effect of winning has two parts. The first part, a graphical analysis, is based on disaggregated, daily data. In the second part, we present regression results: the overall dynamic is shown in two-week periods. Afterwards, we reduce the time dimension to a pre/post comparison for the winners versus the runners-up. The pre/postsetting also introduces the differentiation between crisis/non-crisis.

\subsection{Effect of winning a contract}

Graphical analysis The left graph in Figure 4 illustrates the daily effects for employment by comparing the employees of winners and runners-up. Each curve shows a normalized number of employees per working day (Monday to Friday, excluding days of the weekend) over a symmetric window before and after the event. Each auction- and firm-specific time series is normalized by

\footnotetext{
${ }^{9}$ A short-time program was in place in Austria in some sectors, but not in the construction sector. See for example,
} 
the average of the pre-event number of employees of a firm in an auction, before averaging these normalized time series within the two groups. Winners and runners-up develop similarly before the event, but differently afterwards. While both types of firms increase their employment, the winning firms do so to a much larger extent. Employment begins to trend upwards already in the month before the auction for both winner and runner-up firms. We also observe that pre-existing trends in employment are similar for winners and runners-up.

Figure 4: Number of employees of winner and runner-up
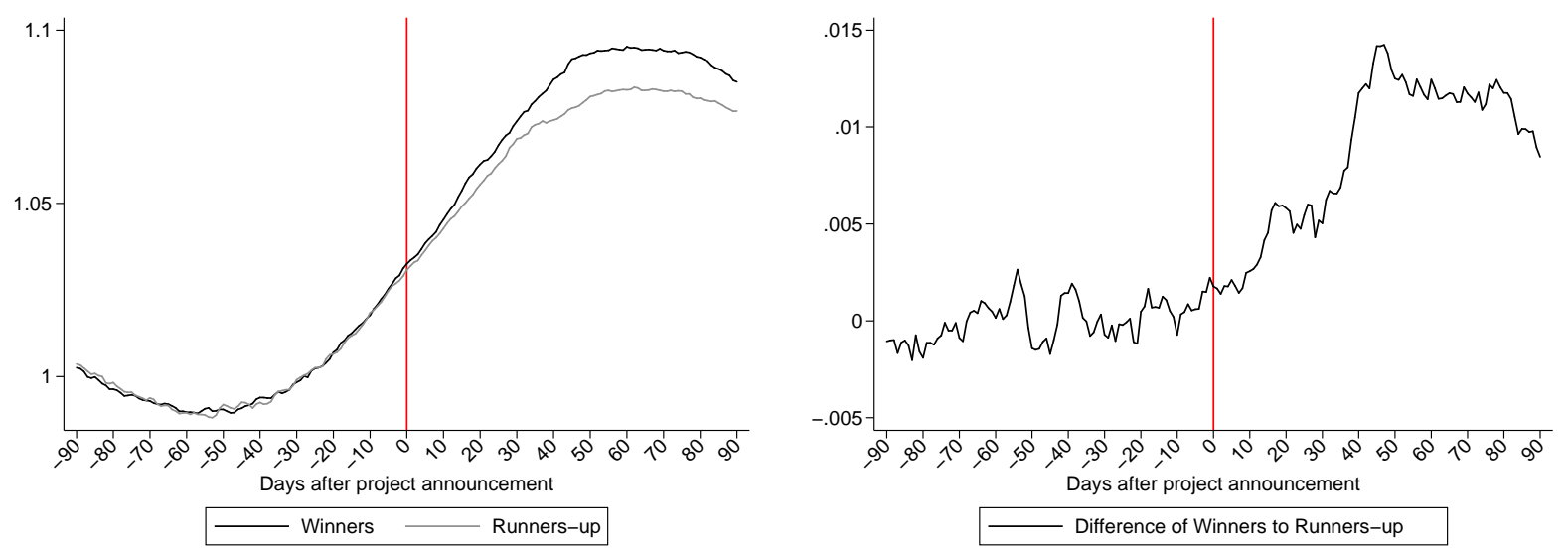

Left graph: For each firm in each auction, the 180 working days time series was divided (normalized) by the average over the 90 working days before the event. The displayed series of employees of the winner (black) and the runner-up (grey) are the group-averages of all the normalized individual, i.e. firm and auction specific, time series.

Right graph: Difference between the normalized number of employees of the winner and runner-up.

On the right-hand side of Figure 4, we show the difference between the number of employees of the winner and runner-up. This is the vertical difference between the two curves of Figure 4's left-hand side series. While there is no discernible difference before the event, a significant effect emerges after the event. Within 45-50 days, the winner employs about 1.5 percent additional employees, relative to the runner-up.

Figure 5 shows the two curves of Figure 4 as well as the curve for the group of bidders formed by ranks 3,4 and 5 on the left. Next to it we show the difference for the winner (black) and runner-up (grey) from the additional group of ranks 3-5. Before the event, employment patterns for winners and runners-up are also similar to ranks 3-5. Afterwards, the runner-up appears close to the lowerranked bidders. The gap of about 1.5 percent more workers between winner and runner-up, again within 40-45 days after the contract has been won, therefore remains.

Bock-Schappelwein et al. (2011). 
Figure 5: Number of employees of winner, runner-up and rank 3, 4, 5
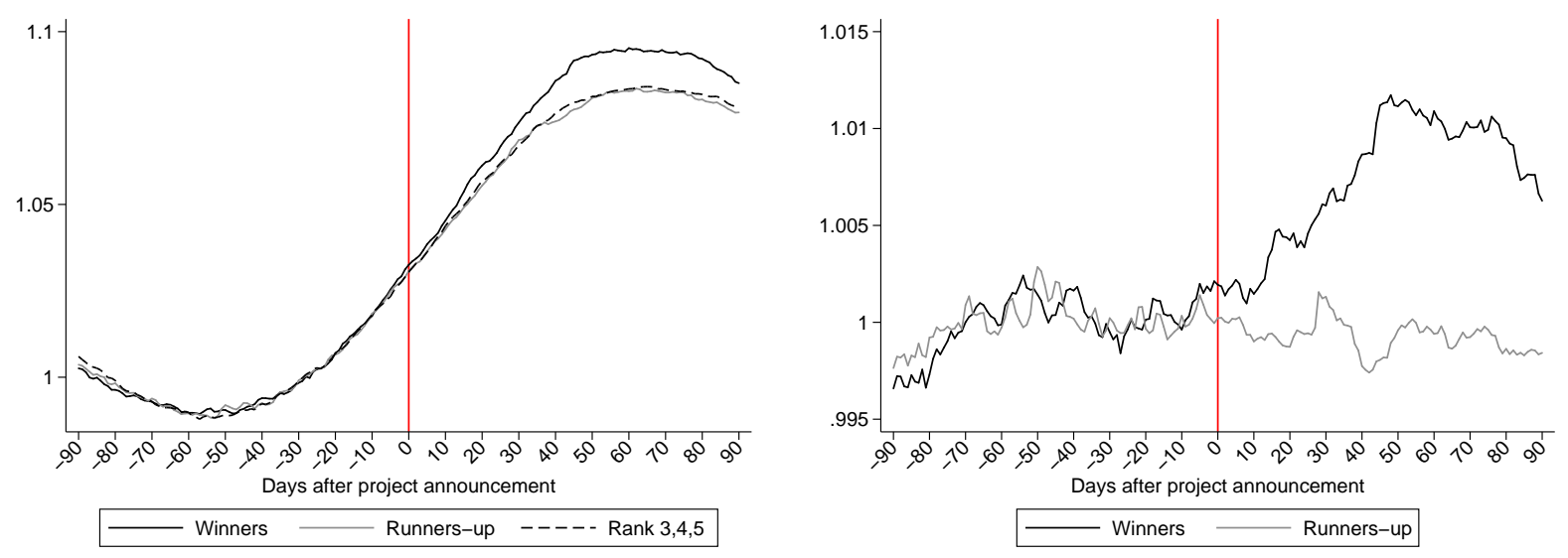

Left graph: For each firm in each auction, the 180 working days time series was divided (normalized) by the average over the 90 working days before the event. The displayed series of employees of the winner (black), the runner-up (grey) and of the three bidders ranking 3rd, 4th and 5th (dashed black) are the group-averages of all the normalized individual, i.e. firm and auction specific, time series.

Right graph: Difference between the normalized number of employees for the winner (black) and runner-up (grey), to the time series of the bidders ranked 3,4 and 5 .

Level results by fortnight Table 3 shows the basic regression results by fortnights. Winner and runner-up start to differ significantly immediately in fortnight 1 after the event $(+47$ employees) and this difference reaches around 73 employees after fortnight 4 (two months), of which about 63 are blue collar workers and 10 are white collar workers. The adjustment of the labor force after winning a contract is fairly fast and around three fourth of the total effect is achieved within one month (after two fortnights). Firms add to their workforce mainly blue collar workers to be able to fulfill their won contracts. We also observe that none of the fortnight dummies interacted with the winner before the auction is significantly different from zero. This confirms again that pre-existing trends in employment are similar for winners and runners-up.

Both types of firms start adding employees from around 3 fortnights before the auction (around 30-40 employees). Winning firms add more workers than runner-up firms before the auction, albeit insignificantly so.

\subsection{Effect of winning a contract before and in the crisis}

For the estimation of the differential effect of the crisis, and the additional results in later sections, we aggregate our data to the simple pre/post-structure described by equation 1. A dummy variable for the recent economic crisis is included. This dummy variable takes the value "1" for auctions 
Table 3: Effect of winning on employment by fortnight

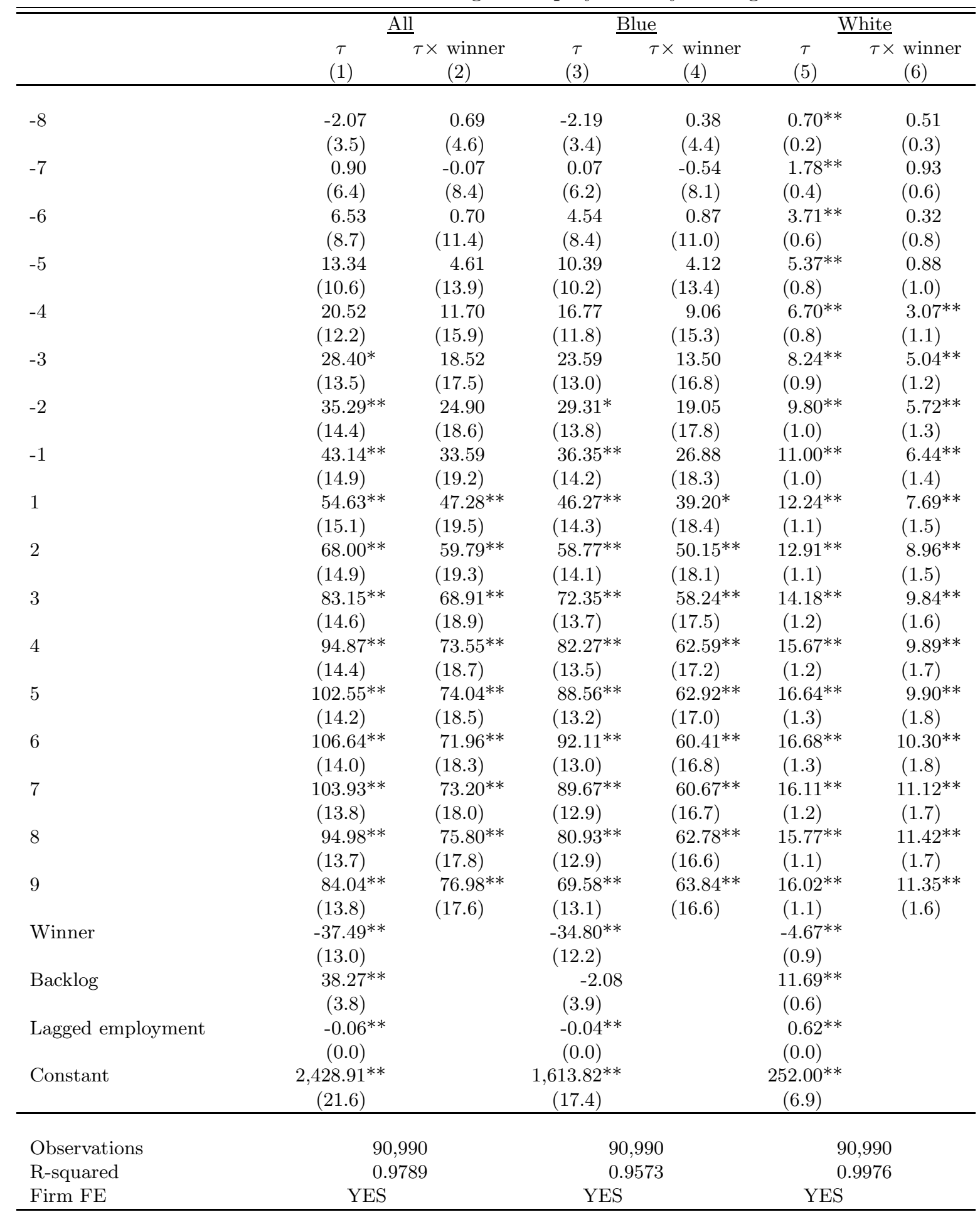

Note: Each numbered line stands for the fortnight relative to the event date, the coefficients measure the effect relative to fortnight -9. Column (1) shows the fortnight estimate, column (2) the fortnight interacted with the dummy for the winner. Columns (3)-(6) repeat the estimates for blue and white collar employees. Backlog after the event, i.e. $\tau>0$, remains constant at the level of $\tau=-1$. Lagged employment is the dependent variable 90 working days before the event. Significance levels: ${ }^{* *} \mathrm{p}<0.01,{ }^{*} \mathrm{p}<0.05$.

with announcement date in and after October 2008, when Austria was hit by the economic crisis,

\footnotetext{
${ }^{10}$ In the Appendix, we present the corresponding results for the sample with pairs only in Table A.4.
} 
until the end of our sample period in 2009.

Levels Regression results are in Table $4 .{ }^{10}$ In columns (1)-(3), we find that winning a construction contract implies that the winner adds workers to its workforce, in particular, it adds blue collar workers. The mean effects are 58 workers, of which 50 are blue collar workers on average. This amounts to 2.1 percent of the winning firm's workforce.

Table 4: Effect of winning a contract on employment

\begin{tabular}{|c|c|c|c|c|c|c|}
\hline & $\begin{array}{l}\text { All } \\
(1) \\
\end{array}$ & $\begin{array}{r}\text { Blue } \\
(2) \\
\end{array}$ & $\begin{array}{r}\text { White } \\
(3) \\
\end{array}$ & $\begin{array}{l}\text { All } \\
(4) \\
\end{array}$ & $\begin{array}{r}\text { Blue } \\
(5) \\
\end{array}$ & $\begin{array}{r}\text { White } \\
(6) \\
\end{array}$ \\
\hline Winner & $\begin{array}{c}-29.29 * * \\
(9.4)\end{array}$ & $\begin{array}{c}-29.22^{* *} \\
(8.9)\end{array}$ & $\begin{array}{l}-2.20^{*} \\
(0.9)\end{array}$ & $\begin{array}{l}-35.27^{* *} \\
(11.1)\end{array}$ & $\begin{array}{l}-28.00^{* *} \\
(10.3)\end{array}$ & $\begin{array}{l}-4.32^{* *} \\
(1.2)\end{array}$ \\
\hline Post & $\begin{array}{l}74.96^{* *} \\
(10.2)\end{array}$ & $\begin{array}{c}62.24^{* *} \\
(9.5)\end{array}$ & $\begin{array}{l}10.83^{* *} \\
(0.8)\end{array}$ & $\begin{array}{l}80.25^{* *} \\
(12.3)\end{array}$ & $\begin{array}{l}63.86^{* *} \\
(11.4)\end{array}$ & $\begin{array}{l}14.27^{* *} \\
(1.1)\end{array}$ \\
\hline Winner $\times$ Post & $\begin{array}{l}57.98^{* *} \\
(13.1)\end{array}$ & $\begin{array}{l}49.75^{* *} \\
(12.0)\end{array}$ & $\begin{array}{l}7.33^{* *} \\
(1.2)\end{array}$ & $\begin{array}{l}80.86^{* *} \\
(15.9)\end{array}$ & $\begin{array}{l}69.45^{* *} \\
(14.5)\end{array}$ & $\begin{array}{c}10.60^{* *} \\
(1.6)\end{array}$ \\
\hline Crisis & & & & $\begin{array}{r}-19.43 \\
(15.8)\end{array}$ & $\begin{array}{l}-63.50^{* *} \\
(15.4)\end{array}$ & $\begin{array}{c}10.93^{* *} \\
(1.3)\end{array}$ \\
\hline Crisis $\times$ Winner & & & & $\begin{array}{r}20.90 \\
(20.2)\end{array}$ & $\begin{array}{r}0.32 \\
(19.7)\end{array}$ & $\begin{array}{l}6.58^{* *} \\
(1.6)\end{array}$ \\
\hline Crisis $\times$ Post & & & & $\begin{array}{r}-16.73 \\
(21.9)\end{array}$ & $\begin{array}{r}-5.13 \\
(20.5)\end{array}$ & $\begin{array}{c}-10.90^{* *} \\
(1.5)\end{array}$ \\
\hline Crisis $\times$ Winner $\times$ Post & & & & $\begin{array}{l}-72.61^{* *} \\
(27.8)\end{array}$ & $\begin{array}{l}-62.50^{*} \\
(26.0)\end{array}$ & $\begin{array}{c}-10.40^{* *} \\
(2.1)\end{array}$ \\
\hline Backlog $_{t<0}$ & $\begin{array}{c}9.88^{*} \\
(4.5)\end{array}$ & $\begin{array}{c}-37.35^{* *} \\
(4.8)\end{array}$ & $\begin{array}{l}11.70^{* *} \\
(0.7)\end{array}$ & $\begin{array}{c}17.08^{* *} \\
(4.2)\end{array}$ & $\begin{array}{c}-20.84^{* *} \\
(4.3)\end{array}$ & $\begin{array}{c}11.19^{* *} \\
(0.7)\end{array}$ \\
\hline Lagged employment & $\begin{array}{l}-0.06^{* *} \\
(0.0)\end{array}$ & $\begin{array}{l}-0.04^{* *} \\
(0.0)\end{array}$ & $\begin{array}{l}0.62^{* *} \\
(0.0)\end{array}$ & $\begin{array}{l}-0.05^{* *} \\
(0.0)\end{array}$ & $\begin{array}{l}-0.05^{* *} \\
(0.0)\end{array}$ & $\begin{array}{l}0.61^{* *} \\
(0.0)\end{array}$ \\
\hline Constant & $\begin{array}{c}2,443.47^{* *} \\
(19.6) \\
\end{array}$ & $\begin{array}{c}1,628.21^{* *} \\
(15.4)\end{array}$ & $\begin{array}{c}259.25^{* *} \\
(7.1) \\
\end{array}$ & $\begin{array}{c}2,447.47^{* *} \\
(19.8) \\
\end{array}$ & $\begin{array}{c}1,650.43^{* *} \\
(14.9) \\
\end{array}$ & $\begin{array}{c}266.08^{* *} \\
(7.7)\end{array}$ \\
\hline Observations & 10,110 & 10,110 & 10,110 & 10,110 & 10,110 & 10,110 \\
\hline R-squared & 0.9889 & 0.9777 & 0.9984 & 0.9890 & 0.9781 & 0.9984 \\
\hline Firm FE & YES & YES & YES & YES & YES & YES \\
\hline
\end{tabular}

Note: Lagged employment is the dependent variable 90 working days before the event. Standard errors are given in parentheses and are clustered on the case-level. Significance levels: ${ }^{* *} \mathrm{p}<0.01,{ }^{*} \mathrm{p}<0.05$.

Columns (4)-(6) show that these mean effects differ dramatically in the crisis period. Winning firms add about 80 workers (69 blue collar workers) to their workforce before the crisis. Back-ofthe-envelope calculations suggest that the share of labor costs as a percentage of total contract value is around $60 \%$ and that average costs per job created by government intervention are around 15,000 euro before the crisis. ${ }^{11}$ In the crisis, however, this effect diminishes to essentially zero. The winning firms add only about 8 workers (7 blue collar workers) to their workforce in the crisis, and

\footnotetext{
${ }^{11}$ Labor costs are equal to: additional number of blue collar workers (69) times the daily wage for blue collar workers (86 euro), plus the additional number of white collar workers (11) times the daily wage for white collar workers (116 euro); times 1.31 (31\% associated employer outlays); times $90 / 5^{*} 7$ (90 working days after winning the contract with the daily wage scaled to 7 days a week, that is $\left(69 * 86+11^{*} 116\right) * 1.31 * 90 / 5 * 7=1,188,672$ euro. Labor costs divided by the average winning bid before the crisis gives $1,188,672 / 1,968,000=0.604$. Average costs per job created are $1,188,672 / 80=14,886$ euro.
} 
these values are not significantly different from zero. Thus, while firms additionally employ people after a positive demand shock elastically in "normal" times, they do not do so in a period of severe crisis.

Firms reacted to the crisis by adjusting their prices and markups. ${ }^{12}$ When it comes to their workforce, firms reacted to the crisis by delivering new projects without adjusting their workforce. Thus, the short-run reaction of labor demand with respect to output is essentially zero in the crisis. Possible explanations include that firms may have started to hoard labor, or have used the crisis to remove inefficiencies in the production process (see the discussion later).

First differences To assess a first robustness of our results, we run our empirical model in first differences, i.e., we compare the difference in average employment after the event from before the event of the winner to this difference of the runner-up. Our model follows Card and Krueger (2000) and again, as Table 5 shows we find that before the crisis winning firms significantly add workers to their workforce (about 60). ${ }^{13}$ While this estimate is somwhat lower than the level results (around 80 employees), results remain qualitatively robust. In the crisis, the winning firms do not add workers as with the level results.

Table 5: First differences for the effect of winning on employment

\begin{tabular}{|c|c|c|c|c|c|c|}
\hline & $\begin{array}{l}\text { All } \\
(1) \\
\end{array}$ & $\begin{array}{r}\text { Blue } \\
(2) \\
\end{array}$ & $\begin{array}{r}\text { White } \\
(3) \\
\end{array}$ & $\begin{array}{l}\text { All } \\
(4) \\
\end{array}$ & $\begin{array}{r}\text { Blue } \\
(5) \\
\end{array}$ & $\begin{array}{r}\text { White } \\
(6) \\
\end{array}$ \\
\hline Winner & $\begin{array}{l}37.63^{* *} \\
(12.8)\end{array}$ & $\begin{array}{l}39.68^{* *} \\
(11.9)\end{array}$ & $\begin{array}{l}1.97 \\
(1.0)\end{array}$ & $\begin{array}{l}60.08^{* *} \\
(15.5)\end{array}$ & $\begin{array}{l}58.95^{* *} \\
(14.3)\end{array}$ & $\begin{array}{l}5.38^{* *} \\
(1.3)\end{array}$ \\
\hline Crisis & & & & $\begin{array}{r}-9.65 \\
(20.0)\end{array}$ & $\begin{array}{r}1.67 \\
(18.8)\end{array}$ & $\begin{array}{c}-10.61^{* *} \\
(1.4)\end{array}$ \\
\hline Crisis $\times$ Winner & & & & $\begin{array}{l}-68.69^{*} \\
(26.7)\end{array}$ & $\begin{array}{c}-59.26^{*} \\
(25.1)\end{array}$ & $\begin{array}{c}-10.20^{* *} \\
(2.0)\end{array}$ \\
\hline Backlog $_{t<0}$ & $\begin{array}{l}-30.65^{* *} \\
(10.8)\end{array}$ & $\begin{array}{l}-24.42^{*} \\
(9.9)\end{array}$ & $\begin{array}{l}-6.15^{* *} \\
(0.8)\end{array}$ & $\begin{array}{c}-21.32^{*} \\
(9.6)\end{array}$ & $\begin{array}{c}-18.13^{*} \\
(8.8)\end{array}$ & $\begin{array}{l}-3.16^{* *} \\
(0.8)\end{array}$ \\
\hline Lagged employment & $\begin{array}{l}0.02^{* *} \\
(0.0)\end{array}$ & $\begin{array}{l}0.02^{*} \\
(0.0)\end{array}$ & $\begin{array}{l}0.02^{\text {** }} \\
(0.0)\end{array}$ & $\begin{array}{l}0.02^{\text {** }} \\
(0.0)\end{array}$ & $\begin{array}{l}0.02^{*} \\
(0.0)\end{array}$ & $\begin{array}{l}0.02^{\text {** }} \\
(0.0)\end{array}$ \\
\hline Constant & $\begin{array}{c}34.23^{* *} \\
(7.5)\end{array}$ & $\begin{array}{c}43.35^{* *} \\
(7.1)\end{array}$ & $\begin{array}{r}0.32 \\
(0.6) \\
\end{array}$ & $\begin{array}{c}37.38^{* *} \\
(9.7) \\
\end{array}$ & $\begin{array}{c}43.02^{\text {** }} \\
(9.1)\end{array}$ & $\begin{array}{l}3.59^{* *} \\
(0.7) \\
\end{array}$ \\
\hline Observations & 5,055 & 5,055 & 5,055 & 5,055 & 5,055 & 5,055 \\
\hline R-squared & 0.0196 & 0.0076 & 0.1676 & 0.0221 & 0.0092 & 0.1970 \\
\hline
\end{tabular}

Notes: Lagged employment is the dependent variable 90 working days before the event. Standard errors are given in parentheses and are clustered on the case-level. Significance levels: ${ }^{* *} \mathrm{p}<0.01,{ }^{*} \mathrm{p}<0.05$.

\footnotetext{
${ }^{12}$ Gugler et al. (2015a) found that the crisis had severe effects on competition in that the negative demand shock led to more bidders and these bid more aggressively. They found a significant decrease of the winning markup in the crisis period of about 4 percentage points relative to a pre-crisis mean winning markup of 22.9 percent.

${ }^{13}$ In the Appendix, we present the corresponding results for the sample with pairs only in Table A.5. Our results also do not change when we add monthly dummy variables to our basic specification in levels or first differences.
} 


\subsection{Description of auctions and firms before and in the crisis}

Our results show a strong and significant difference in the employment change between winning and losing an auction before the recent economic crisis compared to the effects during the crisis. One may suspect that there is not only a difference in employment change, but that there are also systematic differences in the auctions, firms and bidders that participate in the auctions before crisis compared to in the crisis. To rule out these competing explanations, we thus show summary statistics for the main variables describing auctions, firms and bidders in our sample across time.

Table 6 provides the numbers. We observe a significant increase in the number of bidders participating in the auctions in the crisis. While the total value from contracts in the private sector fell, firms entered procurement auctions more frequently. All other auction characteristics, like the average winning bid, do not change across time. The same is true for the percentage of auctions in heavy construction opposed to building, contracts for which a general constructor was demanded and auctions with an open format. ${ }^{14}$ In addition, we see no differences in firm size. On the other side, firms change their behavior. In the crisis, they bid in auctions that are on average farther away. They also have a higher backlog in the crisis, which is a sign of participating and consequently winning more auctions in the crisis in public procurement auctions since our measure of backlog does only account for public procurement contracts and not contracts from the private sector.

Table 6: Difference before and in the crisis across auctions and firms

\begin{tabular}{llrrrrr}
\hline \hline & & \multicolumn{2}{c}{ before the crisis } & \multicolumn{2}{c}{ in the crisis } & Difference \\
& & mean & s.e. & mean & s.e. & \\
\hline \multirow{3}{*}{ Auctions } & Number of auctions & 1,382 & & 672 & & \\
& Winning bid (mill.) & 1.968 & 0.105 & 2.214 & 0.190 & 0.245 \\
& Order flows (mill.) & 1.734 & 5.065 & 1.693 & 6.222 & $-0.141^{* *}$ \\
& Heavy construction & 0.331 & 0.013 & 0.369 & 0.019 & 0.039 \\
& General contractor & 0.091 & 0.008 & 0.073 & 0.010 & -0.018 \\
& Open format & 0.836 & 0.010 & 0.823 & 0.015 & -0.013 \\
& Number of bidders & 7.394 & 0.084 & 8.125 & 0.124 & $0.730^{* *}$ \\
\hline & & & & & & \\
& Nirms & 578 & & 356 & & \\
& Employees & 114.21 & 20.81 & 268.67 & 151.73 & 154.46 \\
& Backlog & -0.046 & 0.008 & 0.326 & 0.012 & $0.372^{* *}$ \\
& Distance (km) & 128.28 & 1.242 & 134.00 & 1.684 & $5.711^{* *}$ \\
\hline
\end{tabular}

Note: Mean and standard errors. Monetary values in million 2006 euro. Significance levels: ${ }^{* *} \mathrm{p}<0.01,{ }^{*} \mathrm{p}<0.05$.

We may conclude from the summary statistics that the crisis did not make auctions or par-

\footnotetext{
${ }^{14}$ Open format means that the auctions are open to all firms, while in other auctions, the seller invited a restricted sample of firms only.
} 
ticipating firms different. However, in the crisis bidders changed their behavior. This change in behavior coincides with our results concerning employment.

Finally, we assess whether firms are different before and in the crisis by comparing the share of won auctions of the 100 most frequent bidders over time. Figure 6 shows that the share of won contracts before the crisis is positively correlated with the share of won contracts during the crisis. We observe some firms that won contracts before, but none afterwards. In general, however, it seems that the same firms participated and won before and in the crisis.

Figure 6: Share of won auctions before and in the crisis

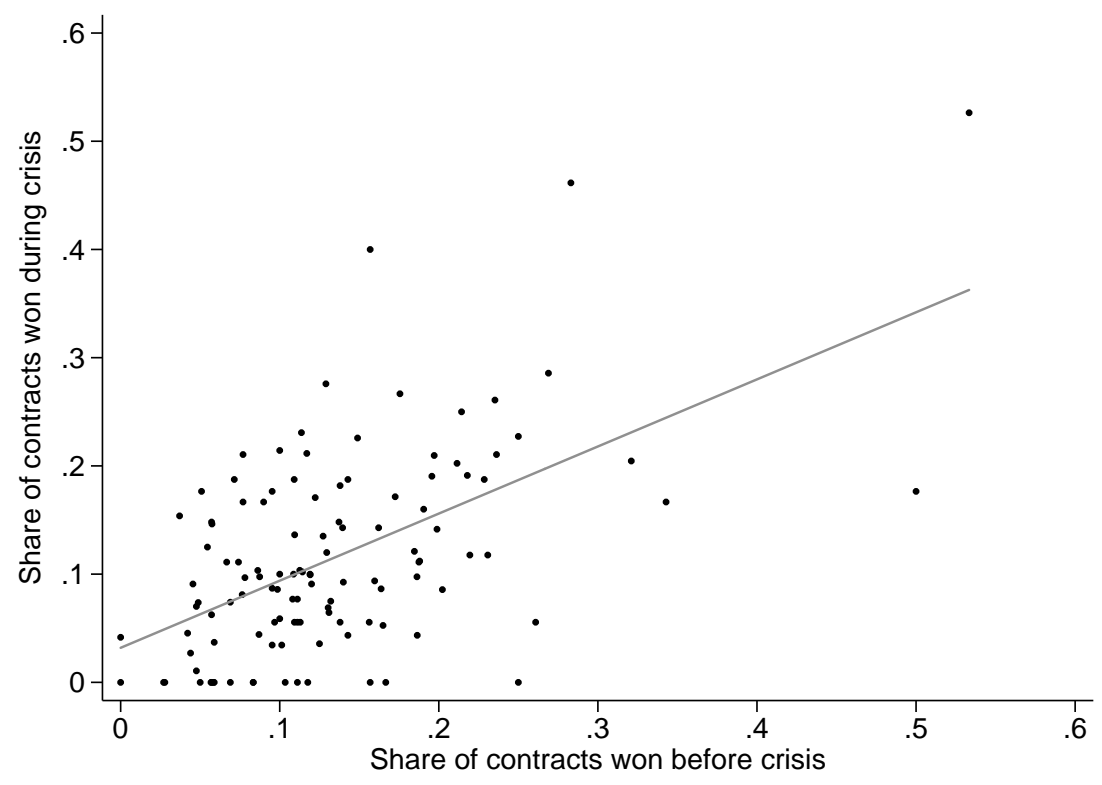

Notes: Firms that are among the 100 most frequent bidders either before or in the crisis. This union of firms yields 116 observations. The 116 firms have submitted 75.94 percent of all bids. The grey line shows the linear regression line (slope $=0.620)$.

Summarizing, systematic observable differences in auctions, firms or bidders cannot explain our findings.

\subsection{Hires and fires}

Our main results showed that the winner of a procurement contract increases its workforce by around 60 workers of which about $85 \%$ are blue collar workers and $15 \%$ are white collar workers. This effect depends on the general state of the economy. Before the recent economic crisis, the winning firm added about 80 workers to its workforce. In the crisis, firms essentially did not add workers. In a further step, we investigate the channels of how firms adjust their workforce. Winning 
firms could hire more workers, or fire fewer workers, or do both, compared to the firm that has marginally not won the contract. Table 7 shows estimation results distinguishing between hires and fires by fortnights for the whole time period as well as for the two sub-periods before and during the crisis.

A firm winning a procurement contract reacts to this shock by significantly firing fewer workers than the runner-up after the event. Before and after the event, winning firms hire and fire fewer workers, thus winning firms generally hold their workforces more stable than runners-up. In the crisis, winning firms' hiring is even more constrained, i.e. winning firms hold their workforces particularly stable in times of crisis. These results are consistent with our results from before using net additions to employment.

\section{$5 \quad$ Further robustness checks}

To substantiate our results, we run further robustness checks. First, we add monthly dummy variables that account for seasonal effects. Second, we include an additional comparison group into our regressions. Third, we control for the probability of winning. Fourth, we account for money left on the table, a measure to assess the differences between the bid of the lowest and the second lowest bidder. Finally, we check whether additional auctions in the evaluation period would contaminate our comparison of winner and runner-up. For all robustness checks, we repeat the basic regressions in levels.

\subsection{Adding monthly dummy variables}

Our first robustness check estimates our basic regression model also including monthly dummy variables. Herewith, we want to accommodate potential seasonal effects that may correlate with the treatment effect. In Austria, the construction sector is characterized by seasonal fluctuations that reflect weather conditions. During winter, construction work usually rests. As Table 8 shows our main results do not change, when we include monthly dummy variables.

\subsection{Ranks 3-5}

In the results presented next, we include a further comparison group: the bidders that rank 3rd, 4th and 5th in each auction. Adding these results serves two purposes. First, it shows that higher 
Table 7: Effect of winning on hires and fires by fortnight

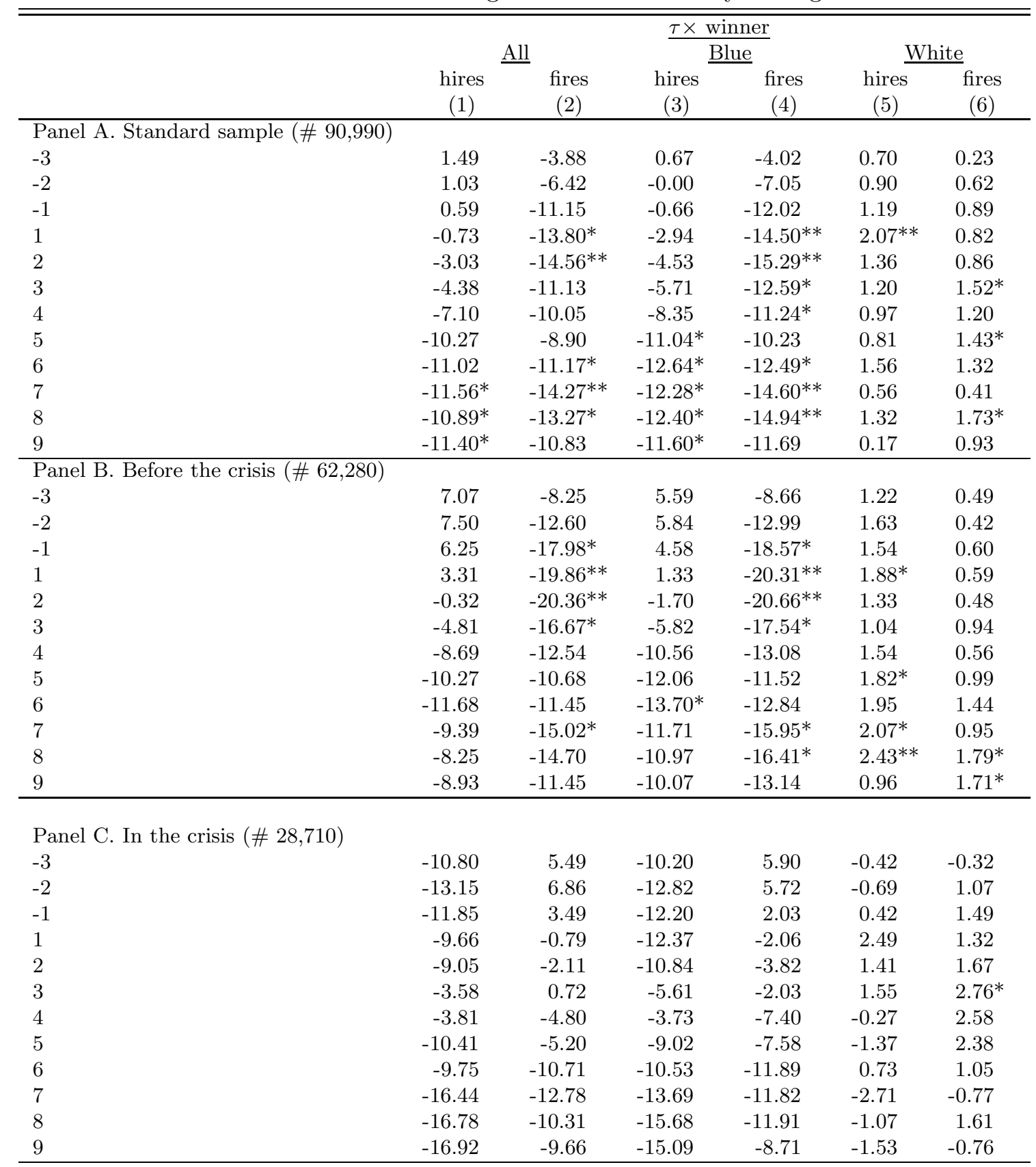

Note: Each numbered line stands for the fortnight relative to the event date. Column (1) shows the fortnight estimate interacted with the dummy for the winner for hires and column (2) for fires. Columns (3)-(6) repeat the estimates for blue and white collar employees. All regressions include the same control variables as earlier regressions as well as fixed effects. Significance levels: ${ }^{* *} \mathrm{p}<0.01,{ }^{*} \mathrm{p}<0.05$.

ranks do not dissipate the effect of winning an auction. Second, it shows that higher ranks are different from the runner-up, too. Choice of ranks 3,4 and 5 is a pragmatic compromise between adding more than only rank number three, but not adding too many ranks which would cause an imbalance by overweighting (in terms of adding numbers of observations) of some auctions which have many bidders compared to auctions that have fewer bidders. Most auctions (about 4 out of 5) have 5 bidders or more. Table 9 presents the results. 
Table 8: Monthly dummies

\begin{tabular}{|c|c|c|c|c|c|c|}
\hline & $\begin{array}{l}\text { All } \\
(1)\end{array}$ & $\begin{array}{r}\text { Blue } \\
(2) \\
\end{array}$ & $\begin{array}{r}\text { White } \\
(3)\end{array}$ & $\begin{array}{l}\text { All } \\
(4)\end{array}$ & $\begin{array}{r}\text { Blue } \\
(5)\end{array}$ & $\begin{array}{r}\text { White } \\
(6) \\
\end{array}$ \\
\hline Winner & $\begin{array}{c}-28.24^{* *} \\
(8.9)\end{array}$ & $\begin{array}{c}-26.23^{* *} \\
(8.4)\end{array}$ & $\begin{array}{l}-3.00^{* *} \\
(0.8)\end{array}$ & $\begin{array}{l}-36.38^{* *} \\
(10.6)\end{array}$ & $\begin{array}{c}-27.45^{* *} \\
(9.7)\end{array}$ & $\begin{array}{l}-5.26^{* *} \\
(1.1)\end{array}$ \\
\hline Post & $\begin{array}{l}74.96^{* *} \\
(10.2)\end{array}$ & $\begin{array}{c}62.24^{* *} \\
(9.5)\end{array}$ & $\begin{array}{l}10.83^{* *} \\
(0.8)\end{array}$ & $\begin{array}{l}80.25^{* *} \\
(12.4)\end{array}$ & $\begin{array}{l}63.86^{* *} \\
(11.4)\end{array}$ & $\begin{array}{l}14.27^{* *} \\
(1.1)\end{array}$ \\
\hline Winner $\times$ Post & $\begin{array}{l}57.98^{* *} \\
(13.1)\end{array}$ & $\begin{array}{l}49.75^{* *} \\
(12.1)\end{array}$ & $\begin{array}{l}7.33^{* *} \\
(1.2)\end{array}$ & $\begin{array}{l}80.86^{* *} \\
(16.0)\end{array}$ & $\begin{array}{l}69.45^{* *} \\
(14.5)\end{array}$ & $\begin{array}{l}10.60^{* *} \\
(1.6)\end{array}$ \\
\hline Crisis & & & & $\begin{array}{c}263.48^{* *} \\
(23.5)\end{array}$ & $\begin{array}{c}178.35^{* *} \\
(18.8)\end{array}$ & $\begin{array}{l}12.44^{* *} \\
(2.4)\end{array}$ \\
\hline Crisis $\times$ Winner & & & & $\begin{array}{r}25.84 \\
(19.3)\end{array}$ & $\begin{array}{r}3.86 \\
(18.8)\end{array}$ & $\begin{array}{l}7.20^{* *} \\
(1.6)\end{array}$ \\
\hline Crisis $\times$ Post & & & & $\begin{array}{r}-16.73 \\
(22.0)\end{array}$ & $\begin{array}{r}-5.13 \\
(20.6)\end{array}$ & $\begin{array}{c}-10.90^{* *} \\
(1.5)\end{array}$ \\
\hline Crisis $\times$ Winner $\times$ Post & & & & $\begin{array}{l}-72.61^{* *} \\
(27.8)\end{array}$ & $\begin{array}{l}-62.50^{*} \\
(26.0)\end{array}$ & $\begin{array}{c}-10.40^{* *} \\
(2.1)\end{array}$ \\
\hline Backlog $_{t<0}$ & $\begin{array}{l}-7.99^{*} \\
(3.2)\end{array}$ & $\begin{array}{c}-33.57^{* *} \\
(3.4)\end{array}$ & $\begin{array}{l}4.66^{* *} \\
(0.5)\end{array}$ & $\begin{array}{c}-7.85^{*} \\
(3.2)\end{array}$ & $\begin{array}{c}-33.19^{* *} \\
(3.4)\end{array}$ & $\begin{array}{l}4.65^{* *} \\
(0.5)\end{array}$ \\
\hline Lagged employment & $\begin{array}{l}-0.04^{* *} \\
(0.0)\end{array}$ & $\begin{array}{l}-0.03^{* *} \\
(0.0)\end{array}$ & $\begin{array}{l}0.64^{* *} \\
(0.0)\end{array}$ & $\begin{array}{l}-0.04^{* *} \\
(0.0)\end{array}$ & $\begin{array}{l}-0.03^{* *} \\
(0.0)\end{array}$ & $\begin{array}{l}0.64^{* *} \\
(0.0)\end{array}$ \\
\hline Constant & $\begin{array}{c}2,287.11^{* *} \\
(22.9) \\
\end{array}$ & $\begin{array}{c}1,533.53^{* *} \\
(16.7) \\
\end{array}$ & $\begin{array}{c}238.36^{* *} \\
(5.8)\end{array}$ & $\begin{array}{c}2,282.79^{* *} \\
(23.2) \\
\end{array}$ & $\begin{array}{c}1,528.50^{* *} \\
(16.8) \\
\end{array}$ & $\begin{array}{c}237.38^{* *} \\
(5.9) \\
\end{array}$ \\
\hline Observations & 10,110 & 10,110 & 10,110 & 10,110 & 10,110 & 10,110 \\
\hline R-squared & 0.9900 & 0.9803 & 0.9987 & 0.9900 & 0.9803 & 0.9987 \\
\hline Firm FE & YES & YES & YES & YES & YES & YES \\
\hline Month FE & YES & YES & YES & YES & YES & YES \\
\hline
\end{tabular}

Notes: Lagged employment is the dependent variable 90 working days before the event. Standard errors are given in parentheses and are clustered on the case-level. Significance levels: ${ }^{* *} \mathrm{p}<0.01,{ }^{*} \mathrm{p}<0.05$.

Our main results concerning the treatment effect of winning are not affected by the inclusion of firms ranked 3-5 in the auctions.

\subsection{Probability of winning}

The motivation for the comparison of winner and runner-up in a quasi-experimental interpretation is that their ex-ante probabilities of winning are similar. For the robustness check in this section, we estimate the probability of winning by a reduced-form linear probability model. (The results of this regression are shown in the Appendix in Table B.2.) From the predictions, we calculate the absolute difference of the winning probabilities of each pair of winner and runner-up. Columns (1)(3) in Table 10 show the results of a t-test that compares the probabilities of winning for the winner and the runner-up. Winners have an ex-ante probability of winning of 16.8 percent, while runnersup have an ex ante probability of 16.2 percent. While the difference is statistically significant, it is not different economically. Nevertheless, we next decrease the absolute difference of winning probabilities between a winner and a runner-up by consecutively excluding the highest percentiles 
Table 9: Robustness rank $>2$

\begin{tabular}{|c|c|c|c|c|c|c|}
\hline & $\begin{array}{l}\text { All } \\
(1) \\
\end{array}$ & $\begin{array}{r}\text { Blue } \\
(2) \\
\end{array}$ & $\begin{array}{r}\text { White } \\
(3) \\
\end{array}$ & $\begin{array}{l}\text { All } \\
(4) \\
\end{array}$ & $\begin{array}{r}\text { Blue } \\
(5) \\
\end{array}$ & $\begin{array}{r}\text { White } \\
(6) \\
\end{array}$ \\
\hline Winner & $\begin{array}{c}-27.97^{* *} \\
(9.1)\end{array}$ & $\begin{array}{c}-27.19^{* *} \\
(8.6)\end{array}$ & $\begin{array}{l}-2.19^{* *} \\
(0.8)\end{array}$ & $\begin{array}{l}-33.87^{* *} \\
(10.8)\end{array}$ & $\begin{array}{l}-25.91^{* *} \\
(10.0)\end{array}$ & $\begin{array}{l}-4.18^{* *} \\
(1.1)\end{array}$ \\
\hline Post & $\begin{array}{l}74.96^{* *} \\
(10.1)\end{array}$ & $\begin{array}{l}62.24^{* *} \\
(9.3)\end{array}$ & $\begin{array}{l}10.83^{* *} \\
(0.8)\end{array}$ & $\begin{array}{l}80.25^{* *} \\
(12.2)\end{array}$ & $\begin{array}{l}63.86^{* *} \\
(11.2)\end{array}$ & $\begin{array}{l}14.27^{* *} \\
(1.1)\end{array}$ \\
\hline Winner $\times$ Post & $\begin{array}{l}57.98^{* *} \\
(12.9)\end{array}$ & $\begin{array}{l}49.75^{* *} \\
(11.9)\end{array}$ & $\begin{array}{l}7.33^{* *} \\
(1.2)\end{array}$ & $\begin{array}{l}80.86^{* *} \\
(15.8)\end{array}$ & $\begin{array}{l}69.45^{* *} \\
(14.3)\end{array}$ & $\begin{array}{l}10.60^{* *} \\
(1.6)\end{array}$ \\
\hline Crisis & & & & $\begin{array}{r}-19.09 \\
(15.4)\end{array}$ & $\begin{array}{l}-65.30^{* *} \\
(15.0)\end{array}$ & $\begin{array}{l}10.71^{* *} \\
(1.2)\end{array}$ \\
\hline Crisis $\times$ Winner & & & & $\begin{array}{r}19.92 \\
(19.6)\end{array}$ & $\begin{array}{r}-1.08 \\
(19.1)\end{array}$ & $\begin{array}{l}6.20^{* *} \\
(1.5)\end{array}$ \\
\hline Crisis $\times$ Post & & & & $\begin{array}{l}-16.73 \\
(21.6)\end{array}$ & $\begin{array}{l}-5.13 \\
(20.3)\end{array}$ & $\begin{array}{c}-10.90^{* *} \\
(1.5)\end{array}$ \\
\hline Crisis $\times$ Winner $\times$ Post & & & & $\begin{array}{l}-72.61^{* *} \\
(27.4)\end{array}$ & $\begin{array}{l}-62.50^{*} \\
(25.7)\end{array}$ & $\begin{array}{c}-10.40^{* *} \\
(2.0)\end{array}$ \\
\hline Rank $>2$ & $\begin{array}{r}6.72 \\
(7.2)\end{array}$ & $\begin{array}{r}6.49 \\
(6.9)\end{array}$ & $\begin{array}{r}0.15 \\
(0.7)\end{array}$ & $\begin{array}{r}19.65 \\
(13.6)\end{array}$ & $\begin{array}{r}25.95 \\
(13.5)\end{array}$ & $\begin{array}{r}-0.97 \\
(0.9)\end{array}$ \\
\hline Rank $>2 \times$ Post & $\begin{array}{l}-19.97 \\
(10.3)\end{array}$ & $\begin{array}{r}-17.77 \\
(9.5)\end{array}$ & $\begin{array}{l}-1.89^{*} \\
(0.9)\end{array}$ & $\begin{array}{l}-16.54 \\
(12.5)\end{array}$ & $\begin{array}{r}-13.97 \\
(11.4)\end{array}$ & $\begin{array}{r}-2.19 \\
(1.2)\end{array}$ \\
\hline Rank $>2 \times$ Crisis & & & & $\begin{array}{r}18.99 \\
(15.9)\end{array}$ & $\begin{array}{r}28.27 \\
(15.6)\end{array}$ & $\begin{array}{r}-1.55 \\
(1.2)\end{array}$ \\
\hline Rank $>2 \times$ Crisis $\times$ Post & & & & $\begin{array}{l}-10.17 \\
(22.1)\end{array}$ & $\begin{array}{r}-11.62 \\
(20.6)\end{array}$ & $\begin{array}{l}1.21 \\
(1.6)\end{array}$ \\
\hline Backlog $_{t<0}$ & $\begin{array}{l}16.90^{* *} \\
(2.7)\end{array}$ & $\begin{array}{c}-19.46^{* *} \\
(2.8)\end{array}$ & $\begin{array}{l}8.95^{* *} \\
(0.4)\end{array}$ & $\begin{array}{l}20.97^{* *} \\
(2.5)\end{array}$ & $\begin{array}{l}-8.89^{* *} \\
(2.5)\end{array}$ & $\begin{array}{l}8.62^{* *} \\
(0.4)\end{array}$ \\
\hline Lagged employment & $\begin{array}{l}-0.06^{* *} \\
(0.0)\end{array}$ & $\begin{array}{l}-0.05^{* *} \\
(0.0)\end{array}$ & $\begin{array}{l}0.64^{* *} \\
(0.0)\end{array}$ & $\begin{array}{l}-0.06^{* *} \\
(0.0)\end{array}$ & $\begin{array}{l}-0.05^{* *} \\
(0.0)\end{array}$ & $\begin{array}{l}0.63^{* *} \\
(0.0)\end{array}$ \\
\hline Constant & $\begin{array}{c}2,004.85^{* *} \\
(13.4) \\
\end{array}$ & $\begin{array}{c}1,339.40^{* *} \\
(10.8)\end{array}$ & $\begin{array}{c}200.89^{* *} \\
(4.7)\end{array}$ & $\begin{array}{c}1,990.12^{* *} \\
(18.3)\end{array}$ & $\begin{array}{c}1,332.53^{* *} \\
(16.3)\end{array}$ & $\begin{array}{c}206.49^{* *} \\
(5.1)\end{array}$ \\
\hline Observations & 22,444 & 22,444 & 22,444 & 22,444 & 22,444 & 22,444 \\
\hline R-squared & 0.9895 & 0.9791 & 0.9984 & 0.9895 & 0.9794 & 0.9984 \\
\hline Firm FE & YES & YES & YES & YES & YES & YES \\
\hline
\end{tabular}

Notes: Lagged employment is the dependent variable 90 working days before the event. Standard errors are given in parentheses and are clustered on the case-level. Significance levels: ${ }^{* *} \mathrm{p}<0.01,{ }^{*} \mathrm{p}<0.05$.

of these differences from the sample until the t-value on the difference test falls below 2 . In the resulting sample, therefore, probabilities of winning for winner and runner-up are not significantly different anymore. Columns (4)-(6) show the result of the t-test for the selected sample.

Table 11 presents the results using this restricted sample, where ex ante winning probabilities of (eventual) winner and runner-up are not statistically different from each other. While the number of added employees decreases a bit to around 68 (from 80 for the main results) before the crisis, the main results stay qualitatively the same.

\subsection{Money left on the table}

Money left on the table (MLOTT) is calculated as the difference between the lowest and the second lowest bid over the lowest bid. Our aim in this robustness check is to use MLOTT as a measure 
Table 10: Probability of winning selection

\begin{tabular}{|c|c|c|c|c|c|c|c|}
\hline \multirow[t]{2}{*}{ Full sample } & \multicolumn{7}{|c|}{ Selected sample } \\
\hline & $\begin{array}{l}\text { Mean } \\
(1)\end{array}$ & $\begin{array}{c}\text { Std. Err. } \\
(2)\end{array}$ & $\begin{array}{c}\text { Obs. } \\
(3)\end{array}$ & & $\begin{array}{c}\text { Mean } \\
(4)\end{array}$ & $\begin{array}{l}\text { Std. Err. } \\
(5)\end{array}$ & $\begin{array}{c}\text { Obs. } \\
(6)\end{array}$ \\
\hline Winner & 16.84 & 0.15 & 1,883 & Winner & 16.71 & 0.16 & 1,789 \\
\hline Runner-up & 16.23 & 0.15 & 1,883 & Runner-up & 16.28 & 0.16 & 1,789 \\
\hline$\Delta$ & 0.60 & 0.22 & & $\Delta$ & 0.42 & 0.22 & \\
\hline t-value & 2.77 & & & t-value & 1.93 & & \\
\hline
\end{tabular}

Notes: Columns (1)-(3) show the results of a t-test that compares the reduced-form-probabilities of winning for the winner and the runner-up. Columns (4)-(6) show the results for the sample selected for the robustness check based on the probabilities of winning. For the subsample, we consecutively exclude the highest percentiles of probability differences from the sample until the t-value on the difference test falls below 2 .

Table 11: Robustness probability of winning selection

\begin{tabular}{|c|c|c|c|c|c|c|}
\hline & $\begin{array}{l}\text { All } \\
(1) \\
\end{array}$ & $\begin{array}{r}\text { Blue } \\
(2) \\
\end{array}$ & $\begin{array}{r}\text { White } \\
(3) \\
\end{array}$ & $\begin{array}{l}\text { All } \\
(4) \\
\end{array}$ & $\begin{array}{r}\text { Blue } \\
(5) \\
\end{array}$ & $\begin{array}{r}\text { White } \\
(6) \\
\end{array}$ \\
\hline Winner & $\begin{array}{l}-30.33^{* *} \\
(10.6)\end{array}$ & $\begin{array}{l}-29.37^{* *} \\
(10.1)\end{array}$ & $\begin{array}{l}-4.26^{* *} \\
(1.3)\end{array}$ & $\begin{array}{l}-36.99^{* *} \\
(12.7)\end{array}$ & $\begin{array}{c}-28.33^{*} \\
(11.8)\end{array}$ & $\begin{array}{l}-6.98^{* *} \\
(1.7)\end{array}$ \\
\hline Post & $\begin{array}{l}79.29^{* *} \\
(11.2)\end{array}$ & $\begin{array}{l}66.38^{* *} \\
(10.4)\end{array}$ & $\begin{array}{l}11.00^{* *} \\
(1.1)\end{array}$ & $\begin{array}{l}86.16^{* *} \\
(13.7)\end{array}$ & $\begin{array}{l}69.40^{* *} \\
(12.6)\end{array}$ & $\begin{array}{l}14.67^{* *} \\
(1.4)\end{array}$ \\
\hline Winner $\times$ Post & $\begin{array}{l}51.77^{* *} \\
(14.6)\end{array}$ & $\begin{array}{l}43.85^{* *} \\
(13.4)\end{array}$ & $\begin{array}{l}7.37^{* *} \\
(1.6)\end{array}$ & $\begin{array}{l}68.34^{* *} \\
(18.3)\end{array}$ & $\begin{array}{l}57.43^{* *} \\
(16.6)\end{array}$ & $\begin{array}{l}10.49^{* *} \\
(2.2)\end{array}$ \\
\hline Crisis & & & & $\begin{array}{r}-19.20 \\
(17.2)\end{array}$ & $\begin{array}{l}-61.79^{* *} \\
(16.8)\end{array}$ & \\
\hline Crisis $\times$ Winner & & & & $\begin{array}{r}22.25 \\
(22.6)\end{array}$ & $\begin{array}{r}0.31 \\
(22.1)\end{array}$ & $\begin{array}{l}8.46^{* *} \\
(2.3)\end{array}$ \\
\hline Crisis $\times$ Post & & & & $\begin{array}{l}-21.40 \\
(23.8)\end{array}$ & $\begin{array}{r}-9.41 \\
(22.3)\end{array}$ & $\begin{array}{c}-11.42^{* *} \\
(2.0)\end{array}$ \\
\hline Crisis $\times$ Winner $\times$ Post & & & & $\begin{array}{r}-51.66 \\
(29.8)\end{array}$ & $\begin{array}{r}-42.33 \\
(27.8)\end{array}$ & $\begin{array}{l}-9.73^{* *} \\
(2.7)\end{array}$ \\
\hline Backlog $\log _{t<0}$ & $\begin{array}{l}16.76^{* *} \\
(5.3)\end{array}$ & $\begin{array}{c}-28.36^{* *} \\
(5.6)\end{array}$ & $\begin{array}{l}3.81^{* *} \\
(1.3)\end{array}$ & $\begin{array}{c}22.80^{* *} \\
(4.9)\end{array}$ & $\begin{array}{c}-13.50^{* *} \\
(5.0)\end{array}$ & $\begin{array}{l}3.75^{* *} \\
(1.3)\end{array}$ \\
\hline Lagged employment & $\begin{array}{l}-0.05^{* *} \\
(0.0)\end{array}$ & $\begin{array}{l}-0.04^{* *} \\
(0.0)\end{array}$ & $\begin{array}{l}0.65^{* *} \\
(0.0)\end{array}$ & $\begin{array}{l}-0.05^{* *} \\
(0.0)\end{array}$ & $\begin{array}{l}-0.04^{* *} \\
(0.0)\end{array}$ & $\begin{array}{l}0.65^{* *} \\
(0.0)\end{array}$ \\
\hline Constant & $\begin{array}{c}2,360.02^{* *} \\
(22.1) \\
\end{array}$ & $\begin{array}{c}1,573.06^{* *} \\
(17.3)\end{array}$ & $\begin{array}{r}-8.04 \\
(6.3)\end{array}$ & $\begin{array}{c}2,364.02^{* *} \\
(22.4)\end{array}$ & $\begin{array}{c}1,593.96^{* *} \\
(16.7)\end{array}$ & $\begin{array}{r}-7.07 \\
(6.4) \\
\end{array}$ \\
\hline Observations & 7,156 & 7,156 & 7,156 & 7,156 & 7,156 & 7,156 \\
\hline R-squared & 0.9892 & 0.9784 & 0.9991 & 0.9892 & 0.9787 & 0.9991 \\
\hline Firm FE & YES & YES & YES & YES & YES & YES \\
\hline Case FE & $\mathrm{NO}$ & $\mathrm{NO}$ & YES & $\mathrm{NO}$ & $\mathrm{NO}$ & YES \\
\hline
\end{tabular}

Notes: Lagged employment is the dependent variable 90 working days before the event. Standard errors are given in parentheses and are clustered on the case-level. Significance levels: $* * \mathrm{p}<0.01,{ }^{*} \mathrm{p}<0.05$.

of the proximity of the bids and bidders' cost valuations ${ }^{15}$ of winner and runner-up, and exclude auctions where winner and runner-up are far from each other in terms of MLOTT. MLOTT is, however, systematically affected by the number of bidders in the auction. Table 12 illustrates the relationship between MLOTT and the number of bidders. Since we want to account for bidding differences between winner and runner-up, we need to account for the effect of the number of

\footnotetext{
${ }^{15}$ If bidders behave optimally in the auction, there is a monotone relation between bids and valuations. For a detailed theoretical analysis of auctions see, for example, Krishna (2009).
} 
bidders on MLOTT. We adjust MLOTT via an OLS-dummy-regression on the number of bidders and use the absolute value of the residuals as the measure for proximity. ${ }^{16}$ The residuals from this regression are simply the difference of an MLOTT-value to its group mean, where a group is defined by the number of bidders in the auction. Auctions with absolute values of the residuals above their 95-percentile-value are excluded from the regressions in this robustness check, to select for increased comparability of winner and runner-up. ${ }^{17}$ Table 13 presents the results. Results remain essentially the same as the main results.

Table 12: Money left on the table

\begin{tabular}{lcrr}
\hline \hline Bidders & $\begin{array}{c}\text { MLOTT } \\
(1)\end{array}$ & $\begin{array}{c}\text { Std. Err. } \\
(2)\end{array}$ & $\begin{array}{r}\text { Obs. } \\
(3)\end{array}$ \\
\hline & & & \\
2 & 0.1538 & 0.0190 & 57 \\
3 & 0.1036 & 0.0102 & 161 \\
4 & 0.0876 & 0.0055 & 285 \\
5 & 0.0808 & 0.0046 & 380 \\
$6-10$ & 0.0666 & 0.0018 & 1,747 \\
$11-22$ & 0.0626 & 0.0040 & 451 \\
\hline
\end{tabular}

Note: MLOTT in column (1) is defined as the difference between the bids of rank 1 and rank 2, relative to the bid of rank 1. The table shows the relationship of MLOTT to the number of bidders.

\subsection{Contamination of evaluation period}

Our empirical model may suffer from contamination of the evaluation period. This could be the case when the winning probability of a firm that wins a contract in period $t$ relative to the winning probability of the runner-up changes due to the winning of the auction. For example, if the winner becomes less likely to win additional auctions after winning the auction in period $t$ relative to the runner-up (say because it becomes more capacity constrained), then we may underestimate the true effect of the auction on labor demand. If the winner becomes more likely to win additional auctions after winning the auction in period $t$ relative to the runner-up (say because of economies scale or scope), then we may overestimate the true effect of the auction on labor demand. While we do not think that this is a large problem in our set-up, since the strategic dynamic effects are small in our sample (see Gugler et al. (2015a)), we performed a robustness check and include in our empirical model a count variable measuring additional auctions won by the winner and the runner-up during the evaluation period, respectively. The results in Table 14 show that our main conclusions are unaffected, if we control for potentially contaminating (additional) public auctions

\footnotetext{
${ }^{16}$ Table B.3 in the Appendix shows the coefficients of the regression. The regression does not include a constant, which makes the coefficients equal to the means of each group.

${ }^{17}$ Taking a 90 -percent-threshold does not change the results, either.
} 
Table 13: Robustness MLOTT

\begin{tabular}{|c|c|c|c|c|c|c|}
\hline & $\begin{array}{l}\text { All } \\
(1)\end{array}$ & $\begin{array}{r}\text { Blue } \\
(2) \\
\end{array}$ & $\begin{array}{r}\text { White } \\
(3) \\
\end{array}$ & $\begin{array}{l}\text { All } \\
(4)\end{array}$ & $\begin{array}{r}\text { Blue } \\
(5) \\
\end{array}$ & $\begin{array}{r}\text { White } \\
(6) \\
\end{array}$ \\
\hline Winner & $\begin{array}{c}-29.52^{* *} \\
(9.6)\end{array}$ & $\begin{array}{c}-30.12^{* *} \\
(9.2)\end{array}$ & $\begin{array}{l}-1.95^{*} \\
(0.9)\end{array}$ & $\begin{array}{l}-34.67^{* *} \\
(11.4)\end{array}$ & $\begin{array}{l}-27.81^{* *} \\
(10.5)\end{array}$ & $\begin{array}{l}-3.99^{* *} \\
(1.2)\end{array}$ \\
\hline Post & $\begin{array}{l}74.59^{* *} \\
(10.5)\end{array}$ & $\begin{array}{l}61.89^{* *} \\
(9.8)\end{array}$ & $\begin{array}{l}10.80^{* *} \\
(0.8)\end{array}$ & $\begin{array}{l}77.85^{* *} \\
(12.8)\end{array}$ & $\begin{array}{l}61.54^{* *} \\
(11.8)\end{array}$ & $\begin{array}{l}14.27^{* *} \\
(1.1)\end{array}$ \\
\hline Winner $\times$ Post & $\begin{array}{l}60.80^{* *} \\
(13.4)\end{array}$ & $\begin{array}{l}52.31^{* *} \\
(12.3)\end{array}$ & $\begin{array}{l}7.52^{* *} \\
(1.2)\end{array}$ & $\begin{array}{l}84.70^{* *} \\
(16.4)\end{array}$ & $\begin{array}{l}72.95^{* *} \\
(14.9)\end{array}$ & $\begin{array}{l}10.79^{* *} \\
(1.6)\end{array}$ \\
\hline Crisis & & & & $\begin{array}{l}-19.24 \\
(16.3)\end{array}$ & $\begin{array}{l}-63.41^{* *} \\
(15.9)\end{array}$ & $\begin{array}{l}11.61^{* *} \\
(1.3)\end{array}$ \\
\hline Crisis $\times$ Winner & & & & $\begin{array}{l}18.19 \\
(20.8)\end{array}$ & $\begin{array}{r}-3.06 \\
(20.3)\end{array}$ & $\begin{array}{l}6.32^{* *} \\
(1.7)\end{array}$ \\
\hline Crisis $\times$ Post & & & & $\begin{array}{l}-10.30 \\
(22.4)\end{array}$ & $\begin{array}{r}1.10 \\
(21.0)\end{array}$ & $\begin{array}{c}-10.94^{* *} \\
(1.6)\end{array}$ \\
\hline Crisis $\times$ Winner $\times$ Post & & & & $\begin{array}{l}-75.62^{* *} \\
(28.3)\end{array}$ & $\begin{array}{l}-65.32^{*} \\
(26.5)\end{array}$ & $\begin{array}{c}-10.36^{* *} \\
(2.1)\end{array}$ \\
\hline Backlog $_{t<0}$ & $\begin{array}{c}10.71^{*} \\
(4.7)\end{array}$ & $\begin{array}{c}-37.42^{* *} \\
(5.0)\end{array}$ & $\begin{array}{l}11.82^{* *} \\
(0.7)\end{array}$ & $\begin{array}{l}17.83^{* *} \\
(4.3)\end{array}$ & $\begin{array}{c}-20.79^{* *} \\
(4.5)\end{array}$ & $\begin{array}{l}11.27^{* *} \\
(0.7)\end{array}$ \\
\hline Lagged employment & $\begin{array}{l}-0.06^{* *} \\
(0.0)\end{array}$ & $\begin{array}{l}-0.04^{* *} \\
(0.0)\end{array}$ & $\begin{array}{l}0.62^{* *} \\
(0.0)\end{array}$ & $\begin{array}{l}-0.05^{* *} \\
(0.0)\end{array}$ & $\begin{array}{l}-0.05^{* *} \\
(0.0)\end{array}$ & $\begin{array}{l}0.60^{* *} \\
(0.0)\end{array}$ \\
\hline Constant & $\begin{array}{c}2,462.24^{* *} \\
(20.2) \\
\end{array}$ & $\begin{array}{c}1,641.73^{* *} \\
(15.9) \\
\end{array}$ & $\begin{array}{c}261.56^{* *} \\
(7.3) \\
\end{array}$ & $\begin{array}{c}2,466.56^{* *} \\
(20.5) \\
\end{array}$ & $\begin{array}{c}1,664.51^{* *} \\
(15.4)\end{array}$ & $\begin{array}{c}269.01^{* *} \\
(8.0)\end{array}$ \\
\hline Observations & 9,608 & 9,608 & 9,608 & 9,608 & 9,608 & 9,608 \\
\hline R-squared & 0.9888 & 0.9776 & 0.9984 & 0.9889 & 0.9780 & 0.9984 \\
\hline Firm FE & YES & YES & YES & YES & YES & YES \\
\hline
\end{tabular}

Notes: Lagged employment is the dependent variable 90 working days before the event. Standard errors are given in parentheses and are clustered on the case-level. Significance levels: ${ }^{* *} \mathrm{p}<0.01,{ }^{*} \mathrm{p}<0.05$.

during the evaluation period. Because of a lack of data from the private sector, we however cannot exclude differential results due to private construction demand.

\section{Discussion}

The results imply a strong reaction of employment to output before the crisis, however a labor demand reaction with respect to output of essentially zero during the economic downturn. We discuss different interpretations and their consistency with this pattern.

\subsection{Labor hoarding}

Labor hoarding is the profit-maximizing practice of firms to retain workers released from finished projects to save, in an effort to maximize profits, on training, hiring, firing and other (quasi-)fixed costs. One explanation for the pattern in our results is that firms change their labor hoarding behavior during the crisis.

The extent of build-up after the event by the winner seems large enough to warrant the view that 
Table 14: Robustness projects won after event

\begin{tabular}{|c|c|c|c|c|c|c|}
\hline & $\begin{array}{l}\text { All } \\
(1) \\
\end{array}$ & $\begin{array}{r}\text { Blue } \\
(2) \\
\end{array}$ & $\begin{array}{r}\text { White } \\
(3) \\
\end{array}$ & $\begin{array}{l}\text { All } \\
(4) \\
\end{array}$ & $\begin{array}{r}\text { Blue } \\
(5) \\
\end{array}$ & $\begin{array}{r}\text { White } \\
(6) \\
\end{array}$ \\
\hline Winner & $\begin{array}{r}-18.66 \\
(9.6)\end{array}$ & $\begin{array}{c}-22.11^{*} \\
(9.2)\end{array}$ & $\begin{array}{r}-0.50 \\
(1.1)\end{array}$ & $\begin{array}{l}-24.08^{*} \\
(11.5)\end{array}$ & $\begin{array}{r}-20.26 \\
(10.9)\end{array}$ & $\begin{array}{r}-1.59 \\
(1.3)\end{array}$ \\
\hline Post & $\begin{array}{l}27.08^{* *} \\
(10.4)\end{array}$ & $\begin{array}{c}30.18^{* *} \\
(9.9)\end{array}$ & $\begin{array}{r}-1.15 \\
(1.2)\end{array}$ & $\begin{array}{l}32.63^{* *} \\
(12.2)\end{array}$ & $\begin{array}{l}30.95^{* *} \\
(11.6)\end{array}$ & $\begin{array}{r}2.54 \\
(1.4)\end{array}$ \\
\hline Winner $\times$ Post & $\begin{array}{l}37.89^{* *} \\
(13.0)\end{array}$ & $\begin{array}{l}36.30^{* *} \\
(12.4)\end{array}$ & $\begin{array}{l}2.31 \\
(1.4)\end{array}$ & $\begin{array}{l}60.31^{* *} \\
(15.6)\end{array}$ & $\begin{array}{l}55.25^{* *} \\
(14.8)\end{array}$ & $\begin{array}{l}5.54^{* *} \\
(1.7)\end{array}$ \\
\hline Crisis & & & & $\begin{array}{r}-19.92 \\
(15.4)\end{array}$ & $\begin{array}{l}-63.93^{* *} \\
(14.6)\end{array}$ & $\begin{array}{l}11.18^{* *} \\
(1.7)\end{array}$ \\
\hline Crisis $\times$ Winner & & & & $\begin{array}{l}20.05 \\
(20.3)\end{array}$ & $\begin{array}{r}-0.28 \\
(19.2)\end{array}$ & $\begin{array}{l}6.57^{* *} \\
(2.2)\end{array}$ \\
\hline Crisis $\times$ Post & & & & $\begin{array}{l}-21.07 \\
(20.7)\end{array}$ & $\begin{array}{r}-8.13 \\
(19.6)\end{array}$ & $\begin{array}{c}-11.97^{* *} \\
(2.3)\end{array}$ \\
\hline Crisis $\times$ Winner $\times$ Post & & & & $\begin{array}{l}-72.63^{* *} \\
(27.7)\end{array}$ & $\begin{array}{c}-62.52^{*} \\
(26.2)\end{array}$ & $\begin{array}{c}-10.40^{* *} \\
(3.1)\end{array}$ \\
\hline Backlog $_{t<0}$ & $\begin{array}{r}9.08 \\
(4.7)\end{array}$ & $\begin{array}{c}-37.97^{* *} \\
(4.5)\end{array}$ & $\begin{array}{c}11.92^{* *} \\
(0.6)\end{array}$ & $\begin{array}{c}16.88^{* *} \\
(4.9)\end{array}$ & $\begin{array}{c}-21.04^{* *} \\
(4.7)\end{array}$ & $\begin{array}{c}11.44^{* *} \\
(0.6)\end{array}$ \\
\hline Lagged employment & $\begin{array}{l}-0.06^{* *} \\
(0.0)\end{array}$ & $\begin{array}{l}-0.05^{* *} \\
(0.0)\end{array}$ & $\begin{array}{l}0.61^{* *} \\
(0.0)\end{array}$ & $\begin{array}{l}-0.06^{* *} \\
(0.0)\end{array}$ & $\begin{array}{l}-0.05^{* *} \\
(0.0)\end{array}$ & $\begin{array}{l}0.60^{* *} \\
(0.0)\end{array}$ \\
\hline Projects won $\times$ Post & $\begin{array}{l}3.05^{* *} \\
(0.2)\end{array}$ & $\begin{array}{l}2.04^{* *} \\
(0.2)\end{array}$ & $\begin{array}{l}0.76^{* *} \\
(0.3)\end{array}$ & $\begin{array}{l}3.12^{* *} \\
(0.2)\end{array}$ & $\begin{array}{l}2.15^{* *} \\
(0.2)\end{array}$ & $\begin{array}{l}0.77^{* *} \\
(0.3)\end{array}$ \\
\hline Constant & $\begin{array}{c}2,443.08^{* *} \\
(16.1)\end{array}$ & $\begin{array}{c}1,626.05^{* *} \\
(11.9)\end{array}$ & $\begin{array}{c}264.18^{* *} \\
(3.9) \\
\end{array}$ & $\begin{array}{c}2,447.04^{* *} \\
(16.7) \\
\end{array}$ & $\begin{array}{c}1,648.34^{* *} \\
(12.6) \\
\end{array}$ & $\begin{array}{c}270.49^{* *} \\
(4.1)\end{array}$ \\
\hline Observations & 10,110 & 10,110 & 10,110 & 10,110 & 10,110 & 10,110 \\
\hline R-squared & 0.9891 & 0.9891 & 0.9779 & 0.9782 & 0.9985 & 0.9985 \\
\hline Firm FE & YES & YES & YES & YES & YES & YES \\
\hline
\end{tabular}

Note: Lagged employment is the dependent variable 90 working days before the event. Standard errors are given in parentheses and are clustered on the case-level. Significance levels: ${ }^{* *} \mathrm{p}<0.01,{ }^{*} \mathrm{p}<0.05$.

most of the necessary workforce for the (average) project won is employed after the announcement. Thus, there is no clear evidence for labor hoarding before the crisis. In the crisis, however, the winner may deploy hoarded workers to the new project, since he does not add workers after winning. Moreover, the fact that winners hold their workforces more stable compared to runners-up is also consistent with (efficient) labor hoarding. The question of course then is why firms react so strongly and timely to the new project before the crisis, but hoard labor during the crisis?

An explanation could lie in a heterogeneous workforce: most of the workforce could be chosen to be of high quality and hoarded over time, only adjusting with workers employed short-term to balance short-term fluctuations of labor demand. When short-term demand is lower during a high level of employment (before the crisis), low quality workers are released timely; when demand is lower at a high level of employment, hoarding sets in to become increasingly more beneficial because it affects high-quality workers. This would be consistent with theoretical reasoning that labor hoarding is more valuable with skilled workers, since fixed costs of training and expertise would be lost if fired. 
Another explanation would involve expectations. Before the crisis expected and realized demand may be more in line with each other than in the crisis, when a severe negative demand shock hits the economy. Thus, before the crisis the winning of an auction occurs at a more optimal utilization rate of capacity (labor and capital), and additional workers have to be employed to fulfill the contract. In the crisis, after the negative demand shock the gap between expected and realized demand widens, and firms do not immediately and fully adjust labor, i.e. they hoard labor, and no additional workers have to be employed to fulfill the contract. Clearly in models of labor hoarding, expectations about future demand (and wages) play a key role (see e.g. Holt et al. (1960), or Oi (1962)).

Summarizing, labor hoarding is obviously consistent with a pattern where the difference between winner and runner-up workforce is not affected by winning a construction contract as we find in the economic crisis. We, however, have to speculate why there is a change in the winner-effect in the crisis. We view heterogenous workforces and a larger mis-alignment of expected and realized demand in the crisis as plausible explanations.

\subsection{Collusion}

Some studies, with a focus of interest on the cyclical behaviour of pricing, have established a theoretical link between business cycles and collusion. Assuming a switch from competition to collusion in the crisis, the collusive environment disconnects the supply shock information from the announcement date of the auction winner. The identification strategy of the employment effect would break down unless the award date is, for some reason, strongly tied to the changes necessary to the workforce in connection with the project.

With varying assumptions on the characteristics of the demand process and the existence of capacity constraints, models have generated a relationship to prices that is countercyclical (Rotemberg and Saloner (1986)), procyclical (Haltiwanger and Harrington (1991); Staiger and Wolak (1992)), or have the ability to predict both patterns, depending on the concrete circumstances (Bagwell and Staiger (1997); Fabra (2006); Knittel and Lepore (2010)). The assumptions on the nature of the business cycles in the studies are a matter of debate, or taste, and empirical models of the construction sector suggest that neither completely unconstrained nor strictly constrained (exogenous or endogenous) capacities are appropriate, but rather an intermediate case between the two (e.g. Gugler et al. (2015a); Jofre-Bonet and Pesendorfer (2003)). None of the models therefore seems to be a strong indicator that a regime switch from competition to collusion causes the difference 
in our employment results. Additionally, it is unclear if firms would be able to break the association between employment behavior and collusion if they think that it could be used as a "test on collusion", e.g. by a competition authority. We acknowledge, though, the possibility that a regime change could produce the changing pattern in our results.

\subsection{Productivity}

Another channel why firms do not employ more people in the crisis after winning an auction could be increased productivity of firms. An important effect of the crisis is an increase in competition as measured by the number of bidders. Indeed we do observe an increase in the average number of bidders during the crisis of about 10 percent, from 7.4 to 8.1 bidders (see Table 6). More competition can lead to a lower labor response after an increase in output demand: firms in more competitive environments have to be more efficient. Competition moves market share toward more efficient producers, shrinking relatively high-cost firms, sometimes forcing their exit. In our auction context an increase in competition leads to less shading of the bids implying that the more efficient firms win more often. One reason why they are more efficient is that they may be able to manage the additional project employing fewer additional employees than other firms. This would be consistent with a small but growing literature in industrial organization analysing the effects of competition on productivity, see e.g Buccirossi et al. (2013) and De Loecker (2011).

\subsection{Stimulus multipliers}

While we cannot estimate fiscal multipliers since we only observe direct (i.e. first round effects) of government procurement projects on employment, we can give a tentative assessment of the likely effectiveness of fiscal stimulus in the crisis. We find that the employment effect of an exogenous increase in demand was essentially zero in the crisis period of our sample. The winner of the auction did not hire more nor fire fewer workers than the runner up. This implies that second round effects of the fiscal stimulus measures were essentially absent in Austria during that time period and that the effects of fiscal stimulus were minor.

\section{$7 \quad$ Summary and conclusions}

We show that winning of a procurement contract increases the workforce of the winner by around 60 workers ( 80 workers before the crisis) or about $2.1 \%$ of its workforce ( $2.8 \%$ before the crisis) 
of which about $85 \%$ are blue collar workers and $15 \%$ are white collar workers. Winning firms, however, do not hire more workers after winning an auction but fire fewer workers than the runnerup thereafter. The effects of the crisis are strong. Winning firms do not increase their number of employees after winning an auction compared to runner-up firms during the crisis. Thus, while we estimate a significant reaction of employment to output before the crisis, we estimate a labor demand reaction with respect to output of essentially zero in the recent economic crisis. We view labor hoarding and productivity increases due to increased competition in the crisis as the most likely explanations.

The results of our approach have strengths, but also some limitations. Runners-up bidding for the same auctions as the winners and losing only by a small margin seem to form a good control group, according to our assessment of relevant variables. Thus, our regression discontinuity design appears to be valid. We can trace employment effects on a daily basis from before the auction to several months after the auction. Through daily information on employment we gain an unusually precise measure for the impact of winning. Moreover, we can disentangle hires and fires. We are not aware of a study that documents evidence on labor demand, hoarding and the recent crisis in such detail. However, our approach allows only a tentative assessment of the likely economic explanations of the observed empirical patterns. 


\section{References}

J. T. Addison, P. Portugal, and J. Varejão. Labor demand research: Toward a better match between better theory and better data. Labour Economics, 30:4-11, 2014.

K. Bagwell and R. Staiger. Collusion over the business cycle. The Rand Journal of Economics, pages 82-106, 1997.

J. E. Biddle. The cyclical behavior of labor productivity and the emergence of the labor hoarding concept. Journal of Economic Perspectives, 28(2):197-211, 2014.

J. Bock-Schappelwein, H. Mahringer, and E. Rückert. Kurzarbeit in Deutschland und Österreich: Endbericht. AMS Österreich, 2011.

S. Bond and J. Van Reenen. Microeconometric models of investment and employment. Handbook of econometrics, 6:4417-4498, 2007.

T. F. Bresnahan, E. Brynjolfsson, and L. M. Hitt. Information technology, workplace organization, and the demand for skilled labor: Firm-level evidence. The Quarterly Journal of Economics, 117 (1):339-376, 2002.

G. Bresson, F. Kramarz, and P. Sevestre. Dynamic labour demand models. In The Econometrics of Panel Data, pages 660-684. Springer, 1996.

P. Buccirossi, L. Ciari, T. Duso, G. Spagnolo, and C. Vitale. Competition policy and productivity growth: An empirical assessment. Review of Economics and Statistics, 95(4):1324-1336, 2013.

D. Card and A. B. Krueger. Minimum wages and employment: A case study of the fast-food industry in New Jersey and Pennsylvania. The American Economic Review, 90(5):1397-1420, 2000.

R. E. Caves. Industrial organization and new findings on the turnover and mobility of firms. Journal of economic literature, 36(4):1947-1982, 1998.

G. Chodorow-Reich, L. Feiveson, Z. Liscow, and W. G. Woolston. Does state fiscal relief during recessions increase employment? evidence from the american recovery and reinvestment act. American Economic Journal: Economic Policy, 4(3):118-45, 2012.

J. De Loecker. Product differentiation, multiproduct firms, and estimating the impact of trade liberalization on productivity. Econometrica, 79(5):1407-1451, 2011. 
N. Fabra. Collusion with capacity constraints over the business cycle. International Journal of Industrial Organization, 24(1):69-81, 2006.

G. Faggio and H. Overman. The effect of public sector employment on local labour markets. Journal of Urban Economics, 79:91-107, 2014.

C. Ferraz, F. Finan, and D. Szerman. Procuring firm growth: The effects of government purchases on firm dynamics. Working Paper 21219, National Bureau of Economic Research, May 2015. URL http://www.nber.org/papers/w21219.

J. Feyrer and B. Sacerdote. Did the stimulus stimulate? real time estimates of the effects of the american recovery and reinvestment act. Technical report, National Bureau of Economic Research, 2011.

J. Galì and T. van Rens. The vanishing procyclicality of labor productivity. Warwick economics research papers series (TWERPS), 1062, 2015. http://wrap.warwick.ac.uk/68737.

M. Greenstone, R. Hornbeck, and E. Moretti. Identifying agglomeration spillovers: Evidence from winners and losers of large plant openings. Journal of Political Economy, 118(3):536-598, 2010.

K. Gugler and B. B. Yurtoglu. The effects of mergers on company employment in the usa and europe. International Journal of Industrial Organization, 22(4):481-502, 2004.

K. Gugler, M. Weichselbaumer, and C. Zulehner. Competition in the economic crisis: Analysis of procurement auctions. European Economic Review, 73:35-57, 2015a.

K. Gugler, M. Weichselbaumer, and C. Zulehner. Analysis of mergers in first-price auctions. CEPR Working Paper, DP10799, 73, 2015b.

J. Haltiwanger and J. E. J. Harrington. The impact of cyclical demand movements on collusive behavior. The RAND Journal of Economics, pages 89-106, 1991.

D. S. Hamermesh. Labor demand and the structure of adjustment costs. The American Economic Review, 79(4):674-689, 1989.

C. C. Holt, F. Modigliani, J. F. Muth, and H. A. Simon. Planning production, inventories, and work force. Englewood Cliffs, NJ: PrenticeHall, 1960.

P. Huber, H. Oberhofer, and M. Pfaffermayr. Who creates jobs? Econometric modeling and evidence for Austrian firm level data. European Economic Review, 91(8):57-71, 2017. 
M. Jofre-Bonet and M. Pesendorfer. Estimation of a dynamic auction game. Econometrica, 71(5): 1443-1489, 2003.

B. Knight. Endogenous federal grants and crowd-out of state government spending: Theory and evidence from the federal highway aid program. American Economic Review, 92(1):71-92, 2002.

C. R. Knittel and J. J. Lepore. Tacit collusion in the presence of cyclical demand and endogenous capacity levels. International Journal of Industrial Organization, 28(2):131-144, 2010.

F. Kramarz. Comments on "Labor demand research: Toward a better match between better theory and better data". Labour Economics, 30:12, 2014.

V. Krishna. Auction theory. Academic press, 2009.

S. Lachenmaier and H. Rottmann. Effects of innovation on employment: A dynamic panel analysis. International journal of industrial organization, 29(2):210-220, 2011.

D. S. Lee and A. Mas. Long-run impacts of unions on firms: New evidence from financial markets, 1961-1999. The Quarterly Journal of Economics, 127:333-378, 2012.

U. Malmendier, E. Moretti, and F. S. Peters. Winning by losing: Evidence on the long-run effects of mergers. Technical report, National Bureau of Economic Research, 2012.

E. Moretti. Local multipliers. American Economic Review, 100(2):373-77, May 2010. doi: 10.1257/aer.100.2.373. URL http://www . aeaweb.org/articles?id=10.1257/aer.100 .2 .373.

E. Moretti and P. Thulin. Local multipliers and human capital in the United States and Sweden. Industrial and Corporate Change, 22(1):339-362, 2013.

C. J. Nekarda and V. A. Ramey. The cyclical behavior of the price-cost markup. American Economic Journal: Macroeconomics, 3(1):36-59, 2011.

S. Nickell. An investigation of the determinants of manufacturing employment in the United Kingdom. The Review of Economic Studies, 51(4):529-557, 1984.

W. Y. Oi. Labor as a quasi-fixed factor. The Journal of Political Economy, 70(6):538-555, 1962.

J. Parker. On measuring the effects of fiscal policy in recessions. Journal of Economic Literature, 49(3):703-718, 2011.

V. A. Ramey. Can government purchases stimulate the economy? Journal of Economic Literature, 
49(3):673-85, 2011a.

V. A. Ramey. Identifying government spending shocks: It's all in the timing. The Quarterly Journal of Economics, 126(1):1, 2011b.

J. Rotemberg and G. Saloner. A supergame-theoretic model of price wars during booms. The American Economic Review, pages 390-407, 1986.

R. Staiger and F. Wolak. Collusive pricing with capacity constraints in the presence of demand uncertainty. The RAND Journal of Economics, pages 203-220, 1992.

J. Wolfers. Did unilateral divorce laws raise divorce rates? A reconciliation and new results. The American Economic Review, 96(5):1802-1820, 2006.

J. Zweimüller, R. Winter-Ebmer, R. Lalive, A. Kuhn, J.-P. Wuellrich, O. Ruf, and S. Büchi. Austrian Social Security Database. NRN: The Austrian Center for Labor Economics and the Analysis of the Welfare State, Working Paper 0903, 2009. 


\section{A Appendix: Summary statistics and estimation results for pairs only}

Table A.1: Summary statistics, pairs only

\begin{tabular}{lrrrrrr}
\hline \hline & \multicolumn{1}{c}{$\begin{array}{c}\text { Mean } \\
(1)\end{array}$} & $\begin{array}{r}\text { Std. Dev. } \\
(2)\end{array}$ & $\begin{array}{c}\text { 10th } \\
(3)\end{array}$ & $\begin{array}{c}50 \text { th } \\
(4)\end{array}$ & $\begin{array}{c}\text { 90th } \\
(5)\end{array}$ & $\begin{array}{c}\text { Obs. } \\
(6)\end{array}$ \\
\hline Bid of winner & & & & & & \\
Bid of runner-up & $2,083,089$ & $6,736,282$ & 192,207 & 793,557 & $4,016,873$ & 1974 \\
No. of bids & $2,197,508$ & $6,965,109$ & 214,259 & 847,074 & $4,199,660$ & 1974 \\
Employees & 7.36 & 2.99 & 4 & 7 & 11 & 1974 \\
Employees, blue & $2,288.93$ & $2,957.67$ & 50 & 505 & 7,880 & 7896 \\
Employees, white & $1,547.22$ & $1,981.67$ & 29 & 350 & 5,095 & 7896 \\
Wage & 657.12 & 888.35 & 8 & 145 & 2,441 & 7896 \\
Wage, blue & 93.90 & 10.17 & 78.58 & 96.30 & 104.74 & 7896 \\
Wage, white & 85.93 & 8.49 & 75.45 & 87.92 & 93.68 & 7896 \\
Backlog & 116.06 & 11.87 & 101.53 & 120.06 & 125.68 & 7896 \\
Distance & -0.03 & 0.72 & -0.93 & -0.06 & 0.85 & 7896 \\
& 141.12 & 128.46 & 10.58 & 102.12 & 329.73 & 3940 \\
\hline
\end{tabular}

Note: Summary statistics of the winners and runners-up appearing as cases in our sample. Bid appears only once for each case and rank, the number of bids only once per case. The other variables' statistics contain data before and after winning the contract. Backlog is standardized by subtraction of the mean and division by the standard deviation on the firm level. Wages are measured per day. All monetary values are in 2006 euro.

Table A.2: Winners and runners-up (pairs only) as well as ranks 3-5

\begin{tabular}{lrrrrr}
\hline \hline & Winners & $\begin{array}{r}\text { Runners-up } \\
(1)\end{array}$ & $\begin{array}{c}\text { Diff. } \\
(3)\end{array}$ & $\begin{array}{c}\text { Others } \\
(4)\end{array}$ & $\begin{array}{c}\text { Diff. } \\
(5)\end{array}$ \\
\hline Employees & & & & & \\
Employees, blue & $2,634.47$ & $2,523.92$ & -110.55 & $1,844.37$ & $-790.10^{* *}$ \\
Employees, white & $1,766.45$ & $1,693.06$ & -73.39 & $1,240.11$ & $-526.34^{* *}$ \\
Wage & 769.84 & 738.09 & -31.75 & 534.15 & $-235.70^{* *}$ \\
Wage, blue & 94.57 & 94.70 & 0.14 & 93.32 & $-1.25^{* *}$ \\
Wage, white & 86.53 & 86.32 & -0.21 & 85.55 & $-0.98^{* *}$ \\
Backlog & 116.74 & 116.71 & -0.03 & 115.17 & $-1.57^{* *}$ \\
Distance & -0.07 & 0.00 & $0.07^{* *}$ & 0.02 & $0.09^{* *}$ \\
& 153.04 & 148.75 & -4.29 & 144.67 & $-8.38^{* *}$ \\
\hline & & & & & \\
\end{tabular}

Note: Standard errors are given in parentheses. Significance levels: ${ }^{* *} \mathrm{p}<0.01,{ }^{*} \mathrm{p}<0.05$. 
Table A.3: Effect of winning on employment by fortnight

\begin{tabular}{|c|c|c|c|c|c|c|}
\hline & \multicolumn{2}{|c|}{ All } & \multicolumn{2}{|c|}{ Blue } & \multicolumn{2}{|c|}{ White } \\
\hline & $\begin{array}{c}\tau \\
(1)\end{array}$ & $\begin{array}{c}\tau \times \text { winner } \\
(2)\end{array}$ & $\begin{array}{c}\tau \\
(3)\end{array}$ & $\begin{array}{c}\tau \times \text { winner } \\
(4)\end{array}$ & $\begin{array}{c}\tau \\
(5) \\
\end{array}$ & $\begin{array}{c}\tau \times \text { winner } \\
(6)\end{array}$ \\
\hline \multirow[t]{2}{*}{-8} & -1.65 & -1.10 & -2.04 & -1.38 & $0.75^{* *}$ & 0.36 \\
\hline & $(3.6)$ & $(5.0)$ & $(3.5)$ & $(4.8)$ & $(0.2)$ & $(0.4)$ \\
\hline \multirow[t]{2}{*}{-7} & 2.24 & 0.83 & 0.91 & 0.05 & $1.90^{* *}$ & 0.99 \\
\hline & (6.6) & $(9.2)$ & (6.4) & (8.8) & $(0.5)$ & $(0.7)$ \\
\hline \multirow[t]{2}{*}{-6} & 7.93 & 5.59 & 4.82 & 5.13 & $4.02^{* *}$ & 0.76 \\
\hline & $(9.0)$ & $(12.5)$ & (8.7) & $(12.1)$ & $(0.7)$ & $(0.9)$ \\
\hline \multirow[t]{2}{*}{-5} & 14.53 & 9.60 & 9.77 & 9.01 & $6.00^{* *}$ & 0.84 \\
\hline & $(11.1)$ & $(15.3)$ & $(10.7)$ & $(14.7)$ & $(0.8)$ & (1.1) \\
\hline \multirow[t]{2}{*}{-4} & 20.67 & 14.72 & 14.70 & 12.60 & $7.42^{* *}$ & 2.41 \\
\hline & $(12.9)$ & $(17.7)$ & $(12.5)$ & $(17.0)$ & $(0.9)$ & $(1.2)$ \\
\hline \multirow[t]{2}{*}{-3} & 27.12 & 19.25 & 19.82 & 15.44 & $8.89^{* *}$ & $3.97^{* *}$ \\
\hline & $(14.4)$ & $(19.6)$ & $(13.8)$ & $(18.8)$ & $(0.9)$ & $(1.4)$ \\
\hline \multirow[t]{2}{*}{-2} & $33.07^{*}$ & 22.96 & 24.34 & 18.50 & $10.37^{* *}$ & $4.49^{* *}$ \\
\hline & $(15.4)$ & $(21.0)$ & $(14.7)$ & $(20.0)$ & $(1.0)$ & $(1.5)$ \\
\hline \multirow[t]{2}{*}{-1} & $39.93^{* *}$ & 31.88 & $29.86^{*}$ & 26.19 & $11.74^{* *}$ & $5.66^{* *}$ \\
\hline & $(15.9)$ & $(21.7)$ & $(15.2)$ & $(20.6)$ & $(1.1)$ & $(1.6)$ \\
\hline \multirow[t]{2}{*}{1} & $51.81^{* *}$ & $48.23^{*}$ & $40.09^{* *}$ & $40.46^{*}$ & $13.07^{* *}$ & $7.65^{* *}$ \\
\hline & $(16.1)$ & $(21.9)$ & $(15.3)$ & $(20.6)$ & $(1.1)$ & $(1.7)$ \\
\hline \multirow[t]{2}{*}{2} & $65.78^{* *}$ & $62.06^{* *}$ & $53.17^{* *}$ & $52.44^{* *}$ & $13.75^{* *}$ & $9.23^{* *}$ \\
\hline & $(15.9)$ & $(21.5)$ & $(15.0)$ & $(20.1)$ & $(1.2)$ & $(1.8)$ \\
\hline \multirow[t]{2}{*}{3} & $81.64^{* *}$ & $71.51^{* *}$ & $67.42^{* *}$ & $60.71^{* *}$ & $15.06^{* *}$ & $10.27^{* *}$ \\
\hline & $(15.5)$ & $(21.1)$ & $(14.5)$ & $(19.4)$ & $(1.2)$ & $(1.9)$ \\
\hline \multirow[t]{2}{*}{4} & $93.88^{* *}$ & $75.22^{* *}$ & $77.90^{* *}$ & $63.98^{* *}$ & $16.51^{* *}$ & $10.47^{* *}$ \\
\hline & $(15.3)$ & $(20.8)$ & $(14.1)$ & $(19.1)$ & $(1.3)$ & $(2.0)$ \\
\hline \multirow[t]{2}{*}{5} & $101.90^{* *}$ & $74.91^{* *}$ & $84.55^{* *}$ & $63.33^{* *}$ & $17.43^{* *}$ & $10.67^{* *}$ \\
\hline & $(15.1)$ & $(20.7)$ & $(13.9)$ & $(19.0)$ & $(1.4)$ & $(2.0)$ \\
\hline \multirow[t]{2}{*}{6} & $106.52^{* *}$ & $70.14^{* *}$ & $88.73^{* *}$ & $58.46^{* *}$ & $17.38^{* *}$ & $10.74^{* *}$ \\
\hline & $(14.7)$ & $(20.5)$ & $(13.6)$ & $(18.8)$ & $(1.3)$ & $(2.0)$ \\
\hline \multirow[t]{2}{*}{7} & $103.73^{* *}$ & $69.27^{* *}$ & $86.32^{* *}$ & $56.87^{* *}$ & $16.72^{* *}$ & $11.28^{* *}$ \\
\hline & $(14.5)$ & $(20.2)$ & $(13.5)$ & $(18.7)$ & $(1.2)$ & $(1.9)$ \\
\hline \multirow[t]{2}{*}{8} & $94.85^{* *}$ & $71.11^{* *}$ & $77.62^{* *}$ & $58.23^{* *}$ & $16.41^{* *}$ & $11.60^{* *}$ \\
\hline & $(14.4)$ & $(20.0)$ & $(13.6)$ & $(18.6)$ & $(1.2)$ & $(1.9)$ \\
\hline \multirow[t]{2}{*}{9} & $83.31^{* *}$ & $73.64^{* *}$ & $65.67^{* *}$ & $60.36^{* *}$ & $16.72^{* *}$ & $11.76^{* *}$ \\
\hline & $(14.6)$ & $(19.8)$ & $(13.8)$ & $(18.6)$ & $(1.2)$ & $(1.8)$ \\
\hline \multirow[t]{2}{*}{ Winner } & $-41.22^{* *}$ & & $-35.69^{* *}$ & & $-6.15^{* *}$ & \\
\hline & $(14.8)$ & & $(13.8)$ & & $(1.1)$ & \\
\hline \multirow[t]{2}{*}{ Backlog } & $54.95^{* *}$ & & $36.70^{* *}$ & & $6.16^{* *}$ & \\
\hline & $(5.3)$ & & $(5.1)$ & & $(0.7)$ & \\
\hline Lagged employment & $-0.04^{* *}$ & & -0.02 & & $0.65^{* *}$ & \\
\hline & $(0.0)$ & & $(0.0)$ & & $(0.0)$ & \\
\hline Constant & -23.58 & & -6.84 & & $-14.91^{* *}$ & \\
\hline & $(44.5)$ & & $(42.5)$ & & $(4.6)$ & \\
\hline Observations & 71,064 & & 71,064 & & 71,064 & \\
\hline R-squared & 0.9811 & & 0.9626 & & 0.9983 & \\
\hline Firm FE & YES & & YES & & YES & \\
\hline Case FE & YES & & YES & & YES & \\
\hline
\end{tabular}

Note: Each numbered line stands for the fortnight relative to the event date, the coefficients measure the effect relative to fortnight -9 . Column (1) shows the fortnight estimate, column (2) the fortnight interacted with the dummy for the winner. Columns (3)-(6) repeat the estimates for blue and white collar employees. Backlog after the event, i.e. $\tau>0$, remains constant at the level of $\tau=-1$. Lagged employment is the dependent variable 90 working days before the event. Significance levels: ${ }^{* *} \mathrm{p}<0.01,{ }^{*} \mathrm{p}<0.05$. 
Table A.4: Effect of winning on employment, pairs only

\begin{tabular}{|c|c|c|c|c|c|c|}
\hline & $\begin{array}{l}\text { All } \\
(1) \\
\end{array}$ & $\begin{array}{r}\text { Blue } \\
(2) \\
\end{array}$ & $\begin{array}{r}\text { White } \\
(3) \\
\end{array}$ & $\begin{array}{l}\text { All } \\
(4) \\
\end{array}$ & $\begin{array}{r}\text { Blue } \\
(5) \\
\end{array}$ & $\begin{array}{r}\text { White } \\
(6) \\
\end{array}$ \\
\hline Winner & $\begin{array}{l}-36.31^{* *} \\
(11.7)\end{array}$ & $\begin{array}{c}-30.22^{* *} \\
(9.7)\end{array}$ & $\begin{array}{l}-4.22^{* *} \\
(1.2)\end{array}$ & $\begin{array}{c}-42.96^{* *} \\
(14.3)\end{array}$ & $\begin{array}{l}-27.19^{*} \\
(11.4)\end{array}$ & $\begin{array}{c}-7.28^{* *} \\
(1.6)\end{array}$ \\
\hline Post & $\begin{array}{l}75.44^{* *} \\
(12.4)\end{array}$ & $\begin{array}{c}62.84^{* *} \\
(9.8)\end{array}$ & $\begin{array}{l}10.71^{* *} \\
(1.0)\end{array}$ & $\begin{array}{l}82.13^{* *} \\
(15.2)\end{array}$ & $\begin{array}{l}65.90^{* *} \\
(12.0)\end{array}$ & $\begin{array}{c}14.14^{* *} \\
(1.3)\end{array}$ \\
\hline Winner $\times$ Post & $\begin{array}{l}55.54^{* *} \\
(16.6)\end{array}$ & $\begin{array}{l}46.77^{* *} \\
(13.0)\end{array}$ & $\begin{array}{l}8.09^{* *} \\
(1.5)\end{array}$ & $\begin{array}{l}72.07^{* *} \\
(20.9)\end{array}$ & $\begin{array}{l}60.05^{* *} \\
(16.3)\end{array}$ & $\begin{array}{c}11.45^{* *} \\
(2.1)\end{array}$ \\
\hline Crisis & & & & & $\begin{array}{l}-60.60^{* *} \\
(15.9)\end{array}$ & \\
\hline Crisis $\times$ Winner & & & & $\begin{array}{r}20.90 \\
(24.3)\end{array}$ & $\begin{array}{r}-4.50 \\
(21.1)\end{array}$ & $\begin{array}{l}9.60^{* *} \\
(2.2)\end{array}$ \\
\hline Crisis $\times$ Post & & & & $\begin{array}{l}-20.98 \\
(26.2)\end{array}$ & $\begin{array}{r}-9.58 \\
(21.0)\end{array}$ & $\begin{array}{c}-10.76^{* *} \\
(1.9)\end{array}$ \\
\hline Crisis $\times$ Winner $\times$ Post & & & & $\begin{array}{r}-51.89 \\
(33.6)\end{array}$ & $\begin{array}{r}-41.67 \\
(26.8)\end{array}$ & $\begin{array}{c}-10.57^{* *} \\
(2.6)\end{array}$ \\
\hline Backlog $_{t<0}$ & $\begin{array}{r}-11.07 \\
(7.5)\end{array}$ & $\begin{array}{c}-30.37^{* *} \\
(5.3)\end{array}$ & $\begin{array}{l}4.34^{* *} \\
(1.2)\end{array}$ & $\begin{array}{r}-10.89 \\
(7.4)\end{array}$ & $\begin{array}{c}-15.66^{* *} \\
(4.7)\end{array}$ & $\begin{array}{l}4.27^{* *} \\
(1.2)\end{array}$ \\
\hline Lagged employment & $\begin{array}{l}-0.04^{* *} \\
(0.0)\end{array}$ & $\begin{array}{l}-0.04^{* *} \\
(0.0)\end{array}$ & $\begin{array}{l}0.65^{* *} \\
(0.0)\end{array}$ & $\begin{array}{l}-0.04^{* *} \\
(0.0)\end{array}$ & $\begin{array}{l}-0.04^{* *} \\
(0.0)\end{array}$ & $\begin{array}{l}0.65^{* *} \\
(0.0)\end{array}$ \\
\hline Constant & $\begin{array}{r}65.12 \\
(47.2) \\
\end{array}$ & $\begin{array}{c}1,580.17^{* *} \\
(16.5)\end{array}$ & $\begin{array}{r}-6.91 \\
(5.5) \\
\end{array}$ & $\begin{array}{r}63.82 \\
(47.2) \\
\end{array}$ & $\begin{array}{c}1,600.83^{* *} \\
(15.9)\end{array}$ & $\begin{array}{r}-5.85 \\
(5.6) \\
\end{array}$ \\
\hline Observations & 7,896 & 7,896 & 7,896 & 7,896 & 7,896 & 7,896 \\
\hline R-squared & 0.9913 & 0.9783 & 0.9991 & 0.9913 & 0.9786 & 0.9991 \\
\hline Firm FE & YES & YES & YES & YES & YES & YES \\
\hline Case FE & YES & $\mathrm{NO}$ & YES & YES & $\mathrm{NO}$ & YES \\
\hline
\end{tabular}

Notes: Lagged employment is the dependent variable 90 working days before the event. Standard errors are given in parentheses and are clustered on the case-level. Significance levels: ${ }^{* *} \mathrm{p}<0.01,{ }^{*} \mathrm{p}<0.05$.

Table A.5: First differences for the effect of winning on employment, pairs only

\begin{tabular}{|c|c|c|c|c|c|c|}
\hline & $\begin{array}{l}\text { All } \\
(1) \\
\end{array}$ & $\begin{array}{r}\text { Blue } \\
(2) \\
\end{array}$ & $\begin{array}{r}\text { White } \\
(3) \\
\end{array}$ & $\begin{array}{l}\text { All } \\
(4) \\
\end{array}$ & $\begin{array}{r}\text { Blue } \\
(5) \\
\end{array}$ & $\begin{array}{r}\text { White } \\
(6) \\
\end{array}$ \\
\hline Winner & $\begin{array}{c}32.71^{*} \\
(13.6)\end{array}$ & $\begin{array}{l}35.31^{* *} \\
(12.6)\end{array}$ & $\begin{array}{r}2.11 \\
(1.1)\end{array}$ & $\begin{array}{l}47.91^{* *} \\
(17.0)\end{array}$ & $\begin{array}{l}47.55^{* *} \\
(15.7)\end{array}$ & $\begin{array}{l}5.45^{* *} \\
(1.4)\end{array}$ \\
\hline Crisis & & & & $\begin{array}{r}-11.91 \\
(20.2)\end{array}$ & $\begin{array}{r}-1.48 \\
(19.1)\end{array}$ & $\begin{array}{c}-10.12^{* *} \\
(1.5)\end{array}$ \\
\hline Crisis $\times$ Winner & & & & $\begin{array}{l}-45.53 \\
(27.4)\end{array}$ & $\begin{array}{r}-37.03 \\
(25.7)\end{array}$ & $\begin{array}{l}-9.77^{* *} \\
(2.1)\end{array}$ \\
\hline Backlog $_{t<0}$ & $\begin{array}{c}-30.92^{*} \\
(12.1)\end{array}$ & $\begin{array}{c}-25.01^{*} \\
(11.2)\end{array}$ & $\begin{array}{l}-5.94^{* *} \\
(1.0)\end{array}$ & $\begin{array}{l}-24.49^{*} \\
(10.9)\end{array}$ & $\begin{array}{l}-21.15^{*} \\
(10.0)\end{array}$ & $\begin{array}{l}-3.30^{* *} \\
(0.9)\end{array}$ \\
\hline Lagged employment & $\begin{array}{l}0.02^{* *} \\
(0.0)\end{array}$ & $\begin{array}{c}0.02^{*} \\
(0.0)\end{array}$ & $\begin{array}{l}0.02^{* *} \\
(0.0)\end{array}$ & $\begin{array}{l}0.02^{* *} \\
(0.0)\end{array}$ & $\begin{array}{l}0.02^{*} \\
(0.0)\end{array}$ & $\begin{array}{l}0.02^{* *} \\
(0.0)\end{array}$ \\
\hline Constant & $\begin{array}{c}33.16^{* *} \\
(7.4) \\
\end{array}$ & $\begin{array}{l}42.78^{* *} \\
(7.0)\end{array}$ & $\begin{array}{r}-0.07 \\
(0.6) \\
\end{array}$ & $\begin{array}{c}37.23^{* *} \\
(9.9)\end{array}$ & $\begin{array}{c}43.50^{* *} \\
(9.3)\end{array}$ & $\begin{array}{l}3.17^{* *} \\
(0.8) \\
\end{array}$ \\
\hline Observations & 3,948 & 3,948 & 3,948 & 3,948 & 3,948 & 3,948 \\
\hline R-squared & 0.0216 & 0.0083 & 0.1831 & 0.0229 & 0.0089 & 0.2090 \\
\hline
\end{tabular}

Notes: Lagged employment is the dependent variable 90 working days before the event. Standard errors are given in parentheses and are clustered on the case-level. Significance levels: ${ }^{* *} \mathrm{p}<0.01,{ }^{*} \mathrm{p}<0.05$. 
Table A.6: Robustness MLOTT, pairs only

\begin{tabular}{|c|c|c|c|c|c|c|}
\hline & $\begin{array}{l}\text { All } \\
(1)\end{array}$ & $\begin{array}{r}\text { Blue } \\
(2)\end{array}$ & $\begin{array}{r}\text { White } \\
(3) \\
\end{array}$ & $\begin{array}{l}\text { All } \\
(4)\end{array}$ & $\begin{array}{r}\text { Blue } \\
(5) \\
\end{array}$ & $\begin{array}{r}\text { White } \\
(6)\end{array}$ \\
\hline Winner & $\begin{array}{l}-30.08^{* *} \\
(10.5)\end{array}$ & $\begin{array}{c}-30.07^{* *} \\
(9.9)\end{array}$ & $\begin{array}{l}-3.93^{* *} \\
(1.2)\end{array}$ & $\begin{array}{l}-34.30^{* *} \\
(12.8)\end{array}$ & $\begin{array}{c}-25.74^{*} \\
(11.7)\end{array}$ & $\begin{array}{l}-6.92^{* *} \\
(1.6)\end{array}$ \\
\hline Post & $\begin{array}{l}76.16^{* *} \\
(10.9)\end{array}$ & $\begin{array}{l}63.56^{* *} \\
(10.1)\end{array}$ & $\begin{array}{l}10.69^{* *} \\
(1.0)\end{array}$ & $\begin{array}{l}81.28^{* *} \\
(13.5)\end{array}$ & $\begin{array}{l}65.12^{* *} \\
(12.4)\end{array}$ & $\begin{array}{c}14.14^{* *} \\
(1.4)\end{array}$ \\
\hline Winner $\times$ Post & $\begin{array}{l}56.36^{* *} \\
(14.5)\end{array}$ & $\begin{array}{l}47.28^{* *} \\
(13.3)\end{array}$ & $\begin{array}{l}8.34^{* *} \\
(1.6)\end{array}$ & $\begin{array}{l}73.83^{* *} \\
(18.5)\end{array}$ & $\begin{array}{l}61.44^{* *} \\
(16.8)\end{array}$ & $\begin{array}{c}11.66^{* *} \\
(2.2)\end{array}$ \\
\hline Crisis & & & & $\begin{array}{r}-15.47 \\
(16.7)\end{array}$ & $\begin{array}{l}-58.56^{* *} \\
(16.3)\end{array}$ & \\
\hline Crisis $\times$ Winner & & & & $\begin{array}{l}15.17 \\
(22.2)\end{array}$ & $\begin{array}{r}-8.79 \\
(21.6)\end{array}$ & $\begin{array}{l}9.40^{* *} \\
(2.3)\end{array}$ \\
\hline Crisis $\times$ Post & & & & $\begin{array}{l}-16.10 \\
(22.9)\end{array}$ & $\begin{array}{r}-4.88 \\
(21.4)\end{array}$ & $\begin{array}{c}-10.85^{* *} \\
(1.9)\end{array}$ \\
\hline Crisis $\times$ Winner $\times$ Post & & & & $\begin{array}{r}-54.86 \\
(29.3)\end{array}$ & $\begin{array}{r}-44.45 \\
(27.3)\end{array}$ & $\begin{array}{c}-10.46^{* *} \\
(2.7)\end{array}$ \\
\hline Backlog $_{t<0}$ & $\begin{array}{l}16.27^{* *} \\
(5.3)\end{array}$ & $\begin{array}{c}-30.07^{* *} \\
(5.5)\end{array}$ & $\begin{array}{l}4.65^{* *} \\
(1.3)\end{array}$ & $\begin{array}{l}21.83^{* *} \\
(4.9)\end{array}$ & $\begin{array}{c}-15.64^{* *} \\
(4.9)\end{array}$ & $\begin{array}{l}4.59^{* *} \\
(1.3)\end{array}$ \\
\hline Lagged employment & $\begin{array}{l}-0.05^{* *} \\
(0.0)\end{array}$ & $\begin{array}{l}-0.04^{* *} \\
(0.0)\end{array}$ & $\begin{array}{l}0.65^{* *} \\
(0.0)\end{array}$ & $\begin{array}{l}-0.05^{* *} \\
(0.0)\end{array}$ & $\begin{array}{l}-0.04^{* *} \\
(0.0)\end{array}$ & $\begin{array}{l}0.65^{* *} \\
(0.0)\end{array}$ \\
\hline Constant & $\begin{array}{c}2,383.62^{* *} \\
(21.7) \\
\end{array}$ & $\begin{array}{c}1,590.17^{* *} \\
(16.9) \\
\end{array}$ & $\begin{array}{r}-8.31 \\
(5.7) \\
\end{array}$ & $\begin{array}{c}2,386.89^{* *} \\
(22.0) \\
\end{array}$ & $\begin{array}{c}1,610.61^{* *} \\
(16.4)\end{array}$ & $\begin{array}{r}-7.39 \\
(5.8) \\
\end{array}$ \\
\hline Observations & 7,512 & 7,512 & 7,512 & 7,512 & 7,512 & 7,512 \\
\hline R-squared & 0.9891 & 0.9782 & 0.9991 & 0.9891 & 0.9785 & 0.9991 \\
\hline Firm FE & YES & YES & YES & YES & YES & YES \\
\hline Case FE & YES & $\mathrm{NO}$ & YES & YES & $\mathrm{NO}$ & YES \\
\hline
\end{tabular}

Notes: Lagged employment is the dependent variable 90 working days before the event. Standard errors are given in parentheses and are clustered on the case-level. Significance levels: ${ }^{* *} \mathrm{p}<0.01,{ }^{*} \mathrm{p}<0.05$. 


\section{B Appendix: Auxiliary estimation results}

Table B.1: Description of variable in estimation of probability of winning

\begin{tabular}{ll}
\hline \hline & Description \\
Variable & Log of number of bidders in the auction. \\
Backlog & Backlog variable, standardized by firm mean and standard deviation. \\
Backlog sum & Sum of backlog of the other bidders in the auction. \\
New orders & Gross inflow of new contracts, countrywide, per month (mill. 2006 euro). \\
Log(employees) & Log of the number of employees of a bidder. \\
KM & Travel distance in kilometers from a bidder's location to the project site. \\
KM average & Average of all other, competing bidders' distances between their location and the project \\
& site. \\
KM sum & Sum of all other, competing bidders' distances between their location and the project \\
& site. \\
Same postal & Bidder location has the same postal code as project site. \\
Same district & Bidder resides in the district of the project site. \\
Same state & Bidder resides in the state of the project site. \\
Heavy construction & Dummy for auctions in heavy construction sector. \\
General contractor & Dummy for bidders serving as "general contractors". \\
Open procedure & Dummy for auctions following the "open procedure". \\
No. of potent. bidders & Number of potential bidders. \\
\hline
\end{tabular}

Table B.2: Linear regression to estimate the probability of winning

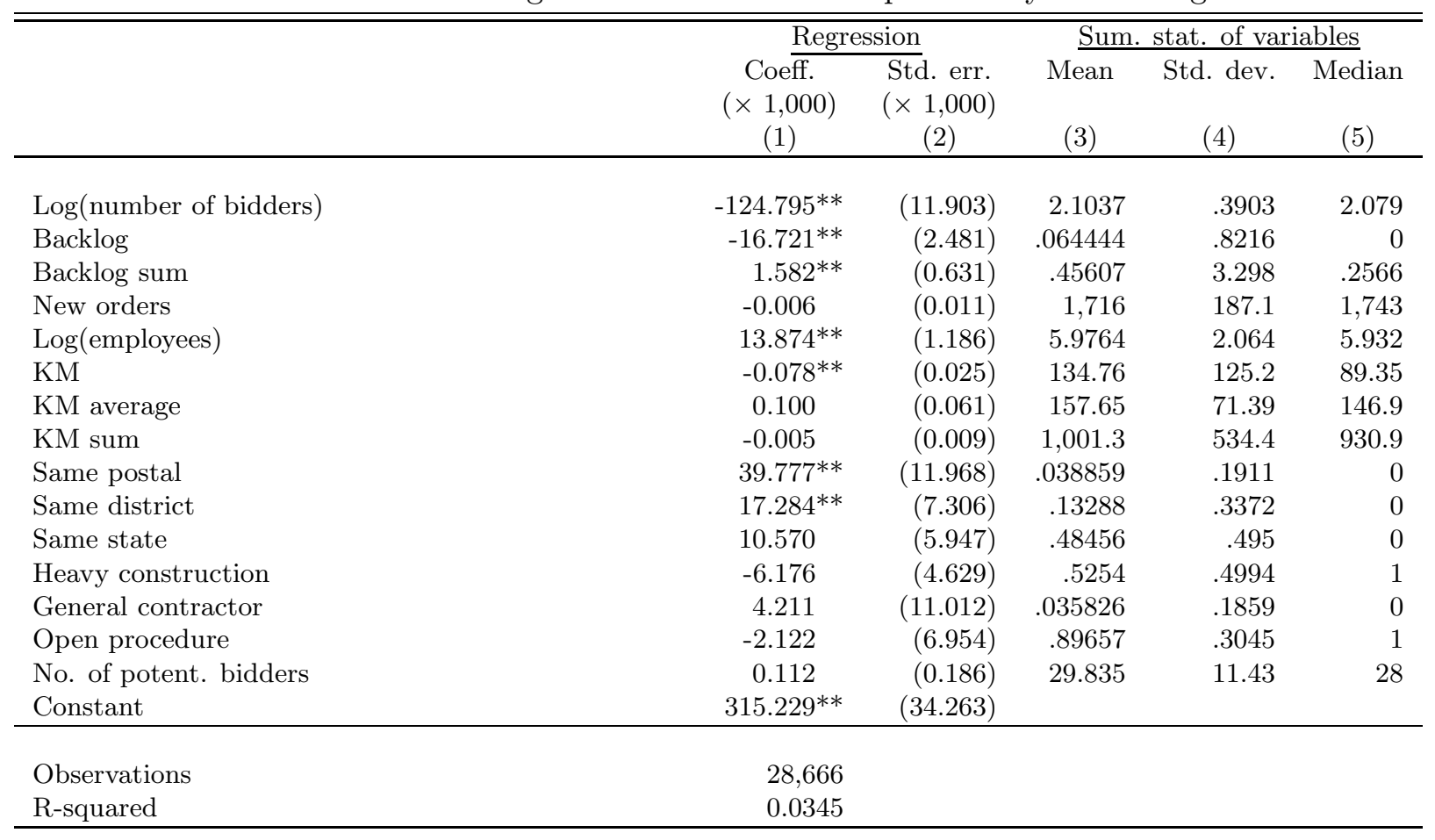

Note: Coefficients of the estimation of the probability of winning are in column (1); their standard errors are given in parentheses in column (2). Columns (3)-(5) show the summary statistics of the explanatory variables. Significance levels: ** $\mathrm{p}<0.01, * \mathrm{p}<0.05$. 
Table B.3: OLS-regression of money left on the table on the number of bidders

\begin{tabular}{llc}
\hline \hline & $\begin{array}{c}\text { Coeff. } \\
(1)\end{array}$ & $\begin{array}{c}\text { Std. err. } \\
(2)\end{array}$ \\
\hline & & $(0.011)$ \\
2 & $0.1538^{* * *}$ & $(0.007)$ \\
3 & $0.1036^{* * *}$ & $(0.005)$ \\
4 & $0.0876^{* * *}$ & $(0.004)$ \\
5 & $0.0808^{* * *}$ & $(0.004)$ \\
6 & $0.0759^{* * *}$ & $(0.004)$ \\
7 & $0.0640^{* * *}$ & $(0.004)$ \\
8 & $0.0616^{* * *}$ & $(0.005)$ \\
9 & $0.0636^{* * *}$ & $(0.006)$ \\
10 & $0.0645^{* * *}$ & $(0.007)$ \\
11 & $0.0587^{* * *}$ & $(0.008)$ \\
12 & $0.0846^{* * *}$ & $(0.010)$ \\
13 & $0.0497^{* * *}$ & $(0.013)$ \\
14 & $0.0557^{* * *}$ & $(0.016)$ \\
16 & $0.0429^{* * *}$ & $(0.021)$ \\
17 & $0.0705^{* * *}$ & $(0.030)$ \\
18 & 0.0459 & $(0.028)$ \\
19 & $0.0519^{*}$ & $(0.060)$ \\
22 & 0.0877 & $(0.085)$ \\
Observations & 0.0429 & $(0.060)$ \\
\hline
\end{tabular}

Note: Results of an OLS-dummy-regression of money left on the table on dummy variables for the number of bidders in each auction. The regression does not include a constant, which makes the coefficients equal to the means of each group. Standard errors are given in parentheses. Significance levels: ${ }^{* *} \mathrm{p}<0.01,{ }^{*} \mathrm{p}<0.05$. 


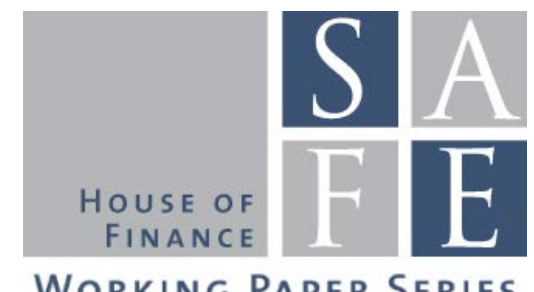

WORKING PAPER SERIES

\section{Recent Issues}

No. 212 Henning Hesse

No. 211 Thomas Mosk

No. 210 Darien Huang, Christian Schlag, Ivan Shaliastovich, Julian Thimme

No. 209 Eren Gürer, Alfons J.

Weichenrieder

No. 208 Roberto Casarin, Michele Costola, Erdem Yenerdag

No. 207 Claes Bäckman, Tobin Hanspal

No. 206 Loriana Pelizzon, Anjan Thakor, Calebe de Roure

No. 205 Horst Entorf, Jia Hou

No. 204 Loriana Pelizzon, Matteo Sottocornola

No. 203 Florian Hett, Felix Schmidt

No. 202 Tobias H. Tröger

No. 201 Dirk Krueger, Alexander Ludwig

No. 200 Nils Grevenbrock, Max Groneck, Alexander Ludwig, Alexander Zimper

No. 199 Tobias H. Tröger

No. 198 Henning Hesse, Boris Hofmann, James Weber
Incentive Effects from Write-down CoCo Bonds: An Empirical Analysis

Bargaining with a Bank

Volatility-of-Volatility Risk

Pro-rich Inflation in Europe: Implications for the Measurement of Inequality

Financial Bridges and Network Communities

The Geography of Alternative Work

P2P Lending versus Banks: Cream Skimming or Bottom Fishing?

Financial Education for the Disadvantaged? A Review

The Impact of Monetary Policy Interventions on the Insurance Industry

Pushing Through or Slacking Off? Heterogeneity in the Reaction to Rank Feedback

Germany's Reluctance to Regulate Related Party Transactions

Optimal Taxes in the OLG Model with Uninsurable Idiosyncratic Income Risk

Cognition, Optimism and the Formation of Age-Dependent Survival Beliefs

Regulation of Crowdfunding in Germany

The Macroeconomic Effect of Asset

Purchases Revisited 